\title{
PEMANFAATAN HARTA WAKAF DI LUAR IKRAR WAKAF PERSPEKTIF HUKUM ISLAM DAN UU NO. 41 TAHUN 2004 \\ (Analisis Pemanfaatan Harta Wakaf di Desa Taman Fajar Kecamatan Purbolinggo Lampung Tengah)
}

\author{
Ahmad Mukhlishin dan Nur Hamidah \\ Universitas Islam Negri Raden Intan Lampung \\ Institut Agama Islam Ma'arif NU Metro Lampung \\ E-mail : ahmadlisin1988@gmail.com, aansuhendri76@gmail.com
}

\begin{abstract}
Abstrak
Wakaf adalah bentuk perbuatan ibadah yang sangat mulia di mata Allah SWT karena memberikan harta bendanya secara cuma-cuma, yang tidak setiap orang bisa melakukannya dan merupakan bentuk kepedulian, tanggung jawab terhadap sesama dan kepentingan umum yang banyak memberikan manfaat. Hukum pemanfaatan tanah wakaf untuk kepentingan usaha pribadi menurut hukum Islam adalah hukumnya haram dan tidak boleh dilakukan. Menurut Undang-undang Nomor 41 Tahun 2004 Tentang Wakaf, memperbolehkan melakukan pengelolaan secara produktif atau usaha di atas tanah wakaf dalam rangka mencapai tujuan dan fungsi wakaf sepanjang tidak bertentangan dengan syariah.
\end{abstract}

Kata Kunci : Harta Wakaf, Hukum Islam, UU No. 41 Tahun 2004

Waqf is a very noble act of worship in the eyes of Allah SWT because it gives his property for free, which not everyone can do and is a form of caring, responsibility to fellow and public interest that many provide benefits. The law of utilizing wakaf land for private business interests according to Islamic law is haram and should not be done. According to Law No. 41 of 2004 on Waqf, permits to conduct productive management or business on wakaf land in order to achieve the goals and functions of waqf as long as it is not contrary to sharia.

Keywords: Wakaf Treasures, Islamic Law, Law no. 41 of 2004 


\section{A. Latar Belakang}

Wakaf sebagai perbuatan hukum sudah lama melembaga dan dipraktikan di Indonesia. Lembaga wakaf juga sudah ada semenjak masuknya agama Islam di Indonesia. Lembaga perwakafan yang dikenal dalam ajaran agama Islam sudah sering dilakukan oleh orang Indonesia yang beragama Islam jauh sebelum kemerdekaan yaitu ketika di Indonesia telah berdiri kerajaan-kerajaan Islam dan pada saat itulah perwakafan sudah dilaksanakan di Indonesia. Jika kita lihat saat ini, perwakafan di Indonesia juga telah mendapat perhatian sebagai contohnya telah banyak dibangun fasilitas peribadatan maupun pendidikan untuk menjamin kelangsungan umat Islam yang dipenuhi dengan cara wakaf. Hal ini disebabkan karena wakaf merupakan suatu lembaga keagamaan yang dapat dipergunakan sebagai salah satu sarana pengembangan hidup beragama khususnya bagi umat Islam dalam rangka mencapai kesejahteraan spiritual dan materil dalam hubungannya dengan bidang sosial masyarakat Islam.

Wakaf merupakan bentuk ajaran Islam yang telah ditanamkan Rasulullah sejak zaman dahulu, banyak ayat al-Qur'an dan Hadits yang menjelaskan akan pentingnya melakukan wakaf, misalkan dalam surat Ali Imron ayat 92 yang artinya:

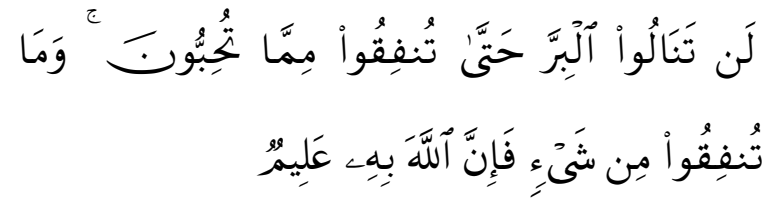

"Kamu sekali-kali tidak sampai kepada kebajikan (yang sempurna) sebelum kamu menafkahkan sebagian harta yang kamu cintai. Dan apa saja yang kamu nafkahkan, maka sesungguhnya Allah mengetahui““1. (QS. Ali Imran; 92)

Ketika mendengar ayat ini, Abu Thalha ingin mewakafkan barha, harta yang ia sukai. Az-Zamakhsyari berkata dalam Al-

1 Departemen Agama RI, Al-Hikmah AlQur'an dan Terjemahnya, Bandung: Diponegoro, 2010. 62 fa'iq bahwa Birha dengan padanan Fa'la dari kata al-birah yaitu tanah yang tinggi, sementara Asy-Syuairi mengatakan ia adalah nama kebun yang terkenal dan pendapat ini diakui oleh Al-Ajhuri.

Firman Allah dalam surat Al-Baqoroh ayat 272 :

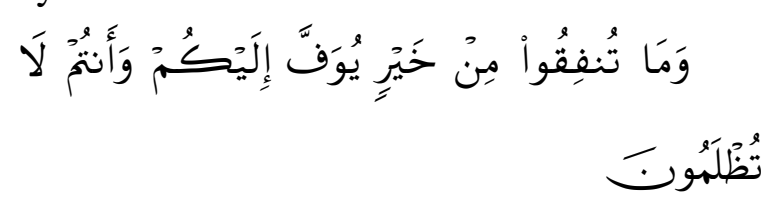

"Dan apa saja harta yang baik yang kamu nafkahkan, niscahya kamu akan diberi pahala dengan cukup." ${ }^{2}$ (Al-Baqarah, (2) : 272)

Sebagian ulama menerjemahkan sedekah jariyah sebagai wakaf,sebab jenis sedekah lainya tidak ada yang tetap mengalir namun tetap dimiliki zat dan manfaatnya adpun wasiat manfaat walaupun termasuk dalam hadis tetapi sangat jarang. Dengan begitu menerjemahkan sedekah dalam hadis dalam arti wakaf lebih utama.

Allah berfiman dalam surat Al-Baqarah ayat 267 :

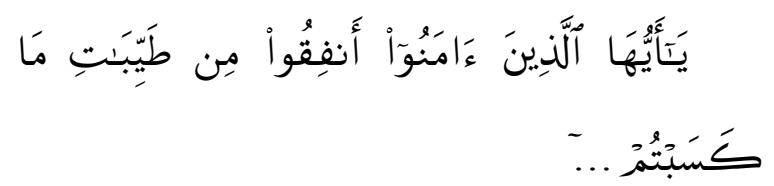

"hai orang-orang yang beriman nafkahkanlah, (dijalan Allah) para ulama sebagian dari usaham yang baik-baik."3 (QS. Al-Baqarah: 267)

Para ulama menilai bahwa wakaf itu rermasuk kategori sedekah jariyah yang nilai pahalanya senantiasa mengalir selagi manfaatnyabisa dipetik. Dalam konteks inilah fukoha mengemukakan hadis nabi yang membicarakan tentang sedekah jariyah sebagai salah satu sandaran wakaf.

Diriwayatkan oleh Abu Hurairah :

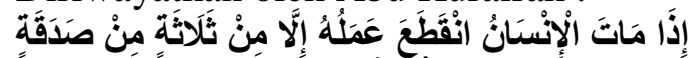

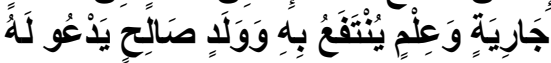

Bahwa Rosul SAW telah bersabda: "apabila meninggl manusia maka terputus pahala segala amalnya kecuali tiga macam, yaitu sedekah jariyah ilmu yang bermanfaat,

\footnotetext{
${ }^{2}$ Departemen Agama RI,. 46

${ }^{3}$ Departemen Agama RI,. 70
} 
atau anak yang soleh yang selalu mendoakanya." 4

Salah satu bentuk wakaf yaitu wakaf tanah. Perwakafan tanah dikatakan sebagai perbuatan kebajikan dikarenakan tanah yang diwakafkan untuk kepentingan sosial masyarakat dan mendatangkan kemaslahatan bagi masyarakat umum serta negara sekalipun. Oleh sebab itu, wakaf tanah bukan sekedar masalah keagamaan namun juga masalah kehidupan masyarakat secara keseluruhan.

Dalam kehidupan manusia keberadaan tanah tidak akan terlepas dari segala kegiatan manusia itu sendiri untuk menjalani dan melanjutkan kehidupannya. Tanah memberikan manfaat kepada manusia salah satunya yaitu manfaat ekonomis. Menurut pendapat Adrian Sutedi mengemukakan bahwa "tanah adalah suatu benda bernilai ekonomis menurut pandangan bangsa Indonesia, ia pula yang sering memberi getaran di dalam kedamaian dan sering pula menimbulkan guncangan dalam masyarakat, lalu ia jua yang sering menimbulkan sendatan dalam pelaksanaan pembangunan". 5

Dari pengertian tanah tersebut mencerminkan begitu penting peranan tanah dalam kehidupan bermasyarakat. Tanah dimanfaatkan sebagai tempat tinggal, kegiatan usaha, kegiatan melakukan pendidikan, kegiatan peribadatan dan lainnya yang dimanfaatkan untuk kemaslahatan masyarakat secara keseluruhan namun jika terjadi suatu persengketaan tanah tentunya tanah akan menimbulkan guncangan dalam masyarakat sesuai pendapat yang dinyatakan oleh Adrian Sutedi tersebut. Pentingnya tanah wakaf juga diakui oleh tatanan Hukum Agraria Nasional yang menyatakan bumi merupakan karunia Tuhan Yang Maha Esa yang mempunyai fungsi sosial sehingga masalah perwakafan tanah harus diakui dan dilindungi oleh negara.

\footnotetext{
${ }^{4}$ Mahmud Syalthut Ali As-Sayis, Fiqih Tujuh Madzhab, Bandung: Pustaka Setia, 2000, 247

5 Adrian Sutedi, Peralihan Hak Atas Tanah dan Pendaftarannya, Jakarta: Sinar Grafika, 2009, 32
}

Lahirnya Undang-Undang Nomor 41 Tahun 2004 tentang Wakaf diharapkan pengembangan wakaf dapat memperoleh dasar hukum yang kuat dan memberikan kepastian hukum kepada wakif baik bagi kelompok orang, organisasi, maupun badan hukum yang mengelola benda-benda wakaf. Disamping itu peraturan ini diharapkan dapat memberikan rasa aman dan melindungi para nadzir dan peruntukkan wakaf (maukuf 'alaih) sesuai dengan manajemen wakaf yang telah di tetapkan.

Adapun bunyi UU No. 41 Tahun 2004 tentang wakaf tersebut ialah: "Wakaf merupakan perbuatan hukum wakif untuk memisahkan dan/atau menyerahkan sebagian harta benda miliknya untuk dimanfaatkan selamanya atau untuk jangka waktu tertentu sesuai dengan kepentingan guna keperluan ibadah dan atau kesejahteraan umum menurut Syariah". 6

Jika kita melihat dalam praktik kehidupan masyarakat pelaksanaan wakaf yang dilaksanakan sejak dahulu hanya dengan pertimbangan agama semata tanpa diiringi pembuktian secara tertulis. Hal demikian dikhawatirkan akan menimbulkan penyalahan dalam peruntukkan tanah wakaf yang di kelola oleh pengelola wakaf sehingga peruntukkan tanah wakaf tersebut tidak sesuai dengan ikrar wakaf. Contohnya saja, pada saat pengucapan ikrar wakaf, tanah tersebut diwakafkan untuk pendirian masjid namun dalam pengelolaan serta pengembangannya pengelola wakaf justru merubah peruntukkan tanah wakaf untuk pendirian sekolah, mardrasah, serta tempattempat umum lainnya. Perubahan peruntukkan tanah wakaf terjadi akibat adanya beberapa hal seperti lokasi masjid yang berdekatan dalam wilayah di mana letaknya tanah wakaf tersebut serta kondisi yang kurang kondusif jika dibangun masjid di tanah wakaf dikarenakan tanah wakaf terletak di tengah-tengah pasar sehingga tidak memungkinkan untuk dibangun masjid.

${ }^{6}$ Siah Khosyi'ah, Wakaf \& Hibah Perspektif Ulama Fiqh dan Perkembangannya di Indonesia, Bandung: Pustaka Setia, 2010, 22-23 
Di dalam masyarakat khususnya di Desa Taman Fajar Purbolinggo yang juga tempat penulis melakukan penelitian, masih ketahui bahwasanya banyak orang yang belum mengetahui bagaimana pemanfaatan harta wakaf di luar ikrar wakaf, ada di dalam masyarakat kita yang salah memanfaatkan harta wakaf yang seharusnya untuk pekarangan mushola namun digunakan untuk menanam hasil perkebunan dan hasilnya untuk pribadi bukan untuk kas mushola tersebut. Kaitan dengan pemanfaatan harta wakaf di luar ikrar wakaf peneliti mencoba untuk meneliti bagaimana pendapat hukum Islam dan UU No. 41 Tahun 2004 tentang harta wakaf tersebut.

\section{B. PEMBAHASAN}

\section{Pengertian Wakaf}

Dari segi bahasa wakaf itu artinya menahan. Menurut istilah fiqih "wakaf itu menahan barang tertentu yang bisa dipindahkan, bisa digunakan tanpa habis dan melepaskan hak pakai untuk kebaikan demi mendekatkan diri kepada Allah". ${ }^{7}$

"Wakaf adalah menahan harta tertentu yang dialihkan hak miliknya dari pihak wakif untuk kepentingan umum. Wujudnya tidak berubah, tujuan pemanfaatannya untuk kebaikan yang dapat mendekatkan diri kepada Allah SWT". ${ }^{8}$

Para Imam Empat bersepakat bahwa wakaf adalah tindakan hukum yang disyari'atkan. Mereka juga sepakat bahwa wakaf mesjid, wakaf ribath (pondok), dan sejenisnya tidak dimaksudkan untuk menjadikan manfaat waqaf itu kepada orang tertentu dan juga tidak dimiliki oleh seseorang. ${ }^{9}$

Menurut istilah syara', "wakaf adalah sejenis pemberian yang pelaksanaannya

7 Mustofa Dieb Al-Bigha, Fiqih Islam Lengkap \& Praktis, Surabaya: Insan Amanah, tt, . 276

${ }^{8}$ Marjuqi Yahya, Panduan Fiqih Imam Safi'I, Jakarta Timur: Al-Maghfirah, tt, 101

${ }^{9}$ Mahmud Syalthut Ali As-Sayis, Fiqih Tujuh Madzhab, Bandung: Pustaka Setia, 2000, 245 dilakukan dengan jalan menahan (pemiliknya) asal (tahbisul ashli), lalu menjadikan manfaatnya berlaku umum". ${ }^{10}$ Dalam hal tersebut, benda yang diwakafkan bukan lagi hak milik yang mewakafkan, dan bukan pula hak milik tempat menyerahkan, tetapi ia menjadi hak milik Allah (hak umum).

Wakaf menurut jumhur ulama' ialah suatu harta yang mungkin dimanfaatkan selagi barangnya utuh. Dengan putusnya hak penggunaan dari wakif, untuk kebajikan yang semata-mata demi mendekatkan diri kepada Allah. Harta wakaf atau hasilnya, dibelanjakan untuk mendekatkan diri kepada Allah. Dengan diwakafkannya harta itu, maka harta keluar dari pemilikan wakif, dan jadilah harta wakaf tersebut secara hukum milik Allah. Bagi wakif, terhalang untuk memanfaatkan dan wajib mendermakan hasilnya sesuai tujuan.

Rumusan yang termuat dalam Kompilasi Hukum Islam, dimana disebutkan dalam pasal 215 ayat (1) bahwa wakaf adalah, perbuatan hukum seseorang atau kelompok orang atau badan hukum yang memisahkan sebagian dari benda miliknya dan melembagakannya untuk selamalamanya, guna kepentingan ibadat atau keperluan umum lainnya sesuai dengan ajaran Islam.Dalam pengertian lain, sebagaimana disebutkan dalam UU RI No 41tahun 2004 tentang wakaf, mendefinisikan wakaf sebagai berikut: "Wakaf adalah perbuatan hukum wakif untuk memisahkan dan/atau menyerahkan sebagian harta benda miliknya, untuk dimanfaatkan selamanya atau untuk jangka waktu tertentu, sesuai dengan kepentingannya guna keperluan ibadah dan atau kesejahteraan umum menurut syari'ah". 11

10 Direktorat Pengembangan Zakat dan Wakaf, Paradigma Baru Wakaf di Indonesia, Direktorat Jendral Bimbingan Masyarakat Islam dan Penyelenggaraan Haji, 2005, Cet. 2, 1.

${ }_{11}$ Kementrian Agama Kabupaten Lampung Timur, Undang-Undang No 41 tahun 2004 Tentang Wakaf, Diperbanyak Oleh Penyelenggara Zakat Wakaf, 2010, 3 
Walau definisi wakaf berbeda antara satu dengan yang lain, akan tetapi definisi tersebut nampaknya berpegang pada prinsip bahwa benda wakaf, pada hakikatnya adalah pengekalan dari manfaat benda wakaf itu.

Namun demikian, dari beberapa definisi dan keterangan di atas, dapatlah ditarik suatu kesimpulan bahwa wakaf itu meliputi beberapa aspek sebagai berikut:

a. Harta benda itu milik yang sempurna.

b. Harta benda itu zatnya bersifat kekal dan tidak habis dalam sekali atau dua kali pakai.

c. Harta benda tersebut dilepaskan kepemilikannya oleh pemiliknya

d. Harta benda yang dilepaskan kepemilikannya tersebut, adalah milik Allah dalam arti tidak dapat dihibahkan, diwariskan atau diperjualbelikan.

Manfaat dari harta benda tersebut untuk kepentingan umum yang sesuai dengan ajaran Islam.

\section{Dasar Hukum Wakaf}

\section{a. Al-Qur'an}

Dalil yang menjadi dasar disyariatkannya ajaran wakaf bersumber dari pemahaman terhadap teks ayatAlQur'an dan juga As-sunah. Tidak ada dalam ayat al-Qur'an yang secara tegas menjelaskan tentang ajaran wakaf. ${ }^{12}$

Kendatipun demikian, karena wakaf itu merupakan salah satu bentuk kebajikan melalui harta benda, jadi ada beberapa ayat yang memerintahkan manusia berbuat baik untuk kebaikan masyarakat, yang disandarkan sebagai landasan atau dasar wakaf, antara lain :

QS. Al-Baqarah, 2: 267

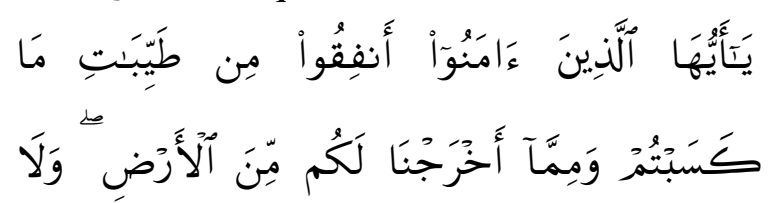

12 Direktorat Pengembangan Zakat dan Wakaf, Op. Cit., 23

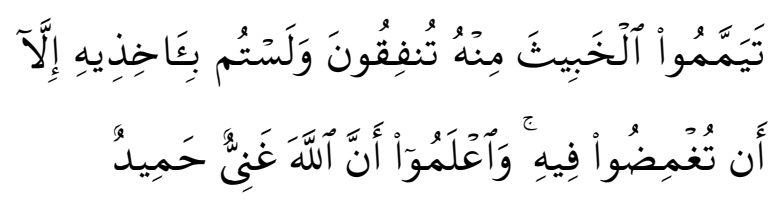

Artinya :"Hai orang-orang yang beriman nafkahkanlah di jalan Allah sebagian dari hasil usahamu yang baik-baik dan sebagian dari apa yang kami keluarkan dari bumi untuk kamu. Dan janganlah kamu memilih yang buruk-buruk lalu kamu nafkahkan dari padanya, padahal kamu sendiri tidak mau mengambilnya melainkan dengan memicingkan mata terhadapnya. Dan ketahuiah bahwa Allah Maha Kaya lagi Maha Terpuji""13. (QS. Al-Baqarah, 2: 267)

Ayat ini menjelaskan bahwa pilihlah yang baik-baik dari apa yang kamunafkahkan itu, walaupun tidak harus semuanya baik, tetapi jangan sampai kamu sengaja memilih yang buruk-buruk lalu kamu nafkahkan darinya. Selanjutnya, ayat ini mengingatkan para pemberi nafkah agar menempatkan diri pada tempat orang yang menerimanya.

Allah memerintahkan pada manusia, agar memberi nafkah kepada yang butuh, bukan karena Allah tidak mampu memberi secara langsung, tetapi perintah ini adalah untuk kepentingan dan kemaslahatan si pemberi.

Kata anfiquu mempunyai arti menafkahkan atau menyedekahkan (wakaf) yang baik-baik untuk diberikan kepada orang yang membutuhkan guna dipergunakan untuk kepentingan umum.

QS. Ali Imran, 3: 92

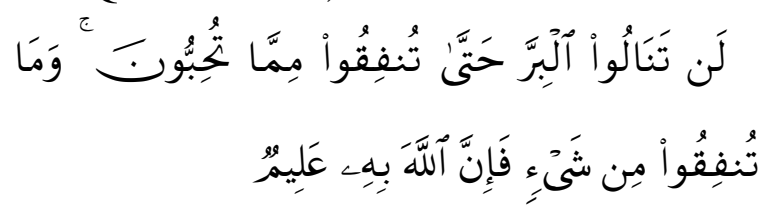

Artinya: Kamu sekali-kali tidak sampai kepada kebaikan (yang sempurna), sebelum kamu nafkahkan sebagian harta yang kamu cintai. Dan apa yang kamu nafkahkan sesungguhnya Allah mengetahuinya". ${ }^{14}$ (QS. Ali Imran, 3: 92)

\footnotetext{
${ }^{13}$ Departemen Agama RI, Al-Hikmah AlQur'an dan Terjemahnya, Bandung: Diponegoro, 2010. 45

${ }^{14}$ Departemen Agama RI,. 45
} 
Penjelasan ayat ini ialah banyak orang yang menafkahkan apa yang ia cintai, tetapi beserta riya. Dan banyak orang yang jiwanya penuh dengan keinginan berbakti, tidak mempunyai harta untuk disedekahkan. Serta kita diperintahkan untuk menyembunyikan sedekah agar tidak menimbulkan riya dalam dada orang yang bersedekah.

Dalam ayat ini Allah menegaskan kepada kita bahwa tanda iman dan neracanya yang benar ialah mengeluarkan harta yang dicintai dijalan Allah dengan ikhlas serta niat yang baik. Tidak dapat seseorang menjadi mukmin yang sempurna kalau tidak mau menyedekahkan harta yang dicintai. Ayat di atas sering digunakan fuqaha' untuk rujukan wakaf.

\section{b. As-Sunnah}

Rasulullah SAW bersabda yang artinya:

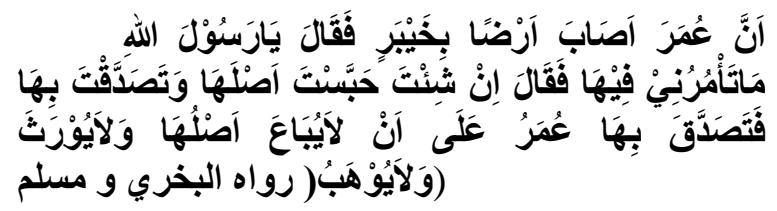

Artinya : "Sesunggunya Umar telah mendapatkan sebidang tanah di Khaibar, Umar bertanya kepada Rasulullah Saw., "Apakah perintahmu kepadaku yang berhubungan dengan tanah yang aku dapat ini?" Jawab beliau, "Jika engkau suka, tahanlah tanah itu dan engkau sedekahkan manfaatnya." Maka dengan pentunjuk beliau itu lalu Umar sedekahkan manfaatnya dengan perjanjian tidak boleh dijual tanahnya, tidak boleh diwariskan (diberikan), dan tidak boleh dihibahkan. (Riwayat Bukhori dan Muslim)" 15

Jadi, kata anfiquu mempunyai arti menafkahkan atau menyedekahkan (wakaf) yang baik-baik untuk diberikan kepada orang yang membutuhkan guna dipergunakan untuk kepentingan umum.

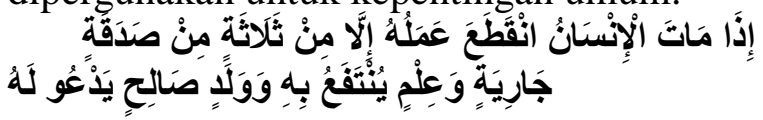

15 Sulaiman Rasjid, Fiqih Islam, Bandung: Sinar Baru Algensindo, 2011, 340
Artinya: "Apabila anak cucu Adam meninggal dunia, terputuslah amalnya kecuali tiga perkara, sedekah jariyah, ilmu yang bermanfaat, dan anak soleh yang mendoakannya" 16

Jelas, maksud dari shadaqah jariyah adalah wakaf. Karena pahala wakaf akan terus menerus mengalir selama barang wakaf itu masih dimanfaatkan. Sebagaimana keutamaan shadaqah jariyah yang manfaat dan pengaruhnya langgeng setelah pemberi sedekah meninggal dunia.

Hadits di atas adalah yang mendasari disyari'atkanya wakaf sebagai tindakan hukum, dengan mendermakan sebagian harta kekayaan untuk kepentingan umum, baik kepentingan sosial maupun kepentingan keagamaan untuk memperoleh pahala dari Allah SWT.

Sedikit sekali memang, ayat-ayat AlQur'an dan Hadits, yang menyinggung tentang wakaf. Karena itu, sedikit sekali hukum-hukum wakaf yang ditetapkan berdasarkan kedua sumber tersebut. Meskipun demikian, ayat Al-Qur'an dan Hadits yang sedikit itu mampu menjadi pedoman para ahli fiqh Islam. Sejak masa Khulafa'ur Rasyidin sampai sekarang, dalam membahas dan mengembangkan hukum-hukum wakaf melalui ijtihad mereka. Sebab itu, sebagian besar hukumhukum wakaf dalam Islam ditetapkan sebagai hasil ijtihad, dengan menggunakan metode ijtihad yang bermacam-macam seperti, qiyas, maslahah mursalah dan lainlain.

Oleh karena itu, ketika suatu hukum (ajaran) Islam yang masuk dalam masalah ijtihadi, maka hal tersebut menjadi sangat fleksibel, terbuka terhadap penafsiranpenafsiran baru, dinamis dan futuristik (berorientasi pada masa depan). Dengan demikian, ditinjau dari aspek ajaran saja, wakaf merupakan sebuah potensi yang cukup besar untuk bisa dikembangkan sesuai dengan kebutuhan zaman. Apalagi ajaran wakaf ini termasuk dari bagian

16 Al-Nawawi, Imam Muhidin, Shahih Muslim, Beirut: Darul Ma'rifah li al-Thaba'ah wa alNasyar wa al-Tauzi, 1992, 1631 
muammalah yang memiliki jangkauan yang lebih luas.

\section{c. Menurut UU No. 41 Tahun 2004 Tentang Wakaf Pasal 1 ayat (1) menyatakan bahwa:}

Wakaf adalah perbuatan hukum wakif untuk memisahkan dan/atau menyerahkan sebagian harta benda miliknya untuk dimanfaatkan selamanya atau untuk jangka waktu tertentu sesuai dengan kepentingannya guna keperluan ibadah dan/atau kesejahteraan umum menurut syariah. ${ }^{17}$

\section{d. Menurut PP No. 42 Tahun 2006 Tentang Pelaksanaan UU No. 41 Tahun 2004 tentang wakaf Pasal 1 ayat (1) menyatakan bahwa:}

Wakaf adalah perbuatan hukum wakif untuk memisahkan dan/atau menyerahkan sebagian harta benda miliknya untuk dimanfaatkan selamanya atau untuk jangka waktu tertentu sesuai dengan kepentingannya guna keperluan ibadah dan/atau kesejahteraan umum menurut Syari'ah. ${ }^{18}$

Dari pengertian di atas dapat dijelaskan bahwa wakaf adalah perbuatan hukum seseorang atau kelompok orang atau badan hukum yang memisahkan sebagian dari benda miliknya dan melembagakannya untuk selama-lamanya guna kepentingan ibadah atau keperluan umum lainnya sesuai dengan ajaran Islam.

\section{Rukun dan Syarat Wakaf}

\section{a. Rukun Wakaf}

Dalam Islam, wakaf dianggap sah jika wakaf itu telah dilaksanakan dengan memenuhi syarat dan rukunnya, sesuai dengan ketentuan-ketentuan yang ada dalam hukum Islam.

${ }^{17}$ Undang-undang Republik Indonesia Nomor 41 TAHUN 2004 Tentang Wakaf, BAB I Ketentuan Umum, Pasal 1 ayat 1,1

18 Peraturan Pemerintah Republik Indonesia Nomor 42 Tahun 2006 Tentang Pelaksanaan Undang-undang Nomor 41 Tahun 2004 Tentang Wakaf BAB I Ketentuan Umum Pasal 1, Ayat 1
"Rukun wakaf ada empat: Redaksi Wakaf, orang yang mewakafkan, barang yang diwakafkan, dan pihak yang menerima wakaf". 19

Wakaf dinyatakan sah apabila telah terpenuhi rukun dan syarat wakaf.Adapun rukun wakaf ada empat yaitu "waqif (pihak yang menyerahkan waqaf), mauquf alaih (pihak yang diserahi waqaf), Mauquf bih (yang diwaqafkan, baik benda maupun manfaat), dan sighat atau iqrar. ${ }^{20}$

Dalam Undang-Undang RI no. 41 tahun 2004 disebutkan enam unsur wakaf yaitu:
a. Wakif
b. Nadzir
c. Harta benda wakaf
d. Ikrar wakaf
e. Peruntukan harta benda wakaf
f. Jangka waktu wakaf ${ }^{21}$

Sempurna atau tidaknya wakaf sangat dipengaruhi oleh rukun dan syarat serta unsur-unsur yang ada dalam perbuatan wakaf. Masing-masing unsur harus saling menopang satu dengan lainnya. Keberadaan yang satu sangat menentukan keberadaan yang lainnya.

\section{b. Syarat Wakaf}

Rukun-rukun yang dikemukakan, masing-masing harus memenuhi syaratsyarat. Jadi, syarat-syarat wakaf masuk pada setiap rukun wakaf, dan setiap rukun wakaf mempunyai syarat masing-masing yang harus ada pada tujuan tersebut, sehingga antara syarat dan rukun wakaf itu menjadi satu rangkaian artinya, saling terkait dan melengkapi.

Untuk sahnya suatu wakaf diperlukan syarat-syarat sebagai berikut (Abdul Ghofur Anshori, 2005:30-31): ${ }^{22}$

1. Wakaf harus dilakukan secara tunai, tanpa digantungkan kepada akan terjadinya sesuatu

${ }^{19}$ Muhammad Jawad, Mughniyah, Fiqih Lima Madhab, Jakarta: Lentera, 2002, Cet. 8, 640.

${ }^{20}$ Siah Khosi'ah, . 39.

${ }^{21}$ Kementrian Agama Kabupaten Lampung Timur,. 5-6

${ }^{22}$ Abdul Ghofur Anshori, Hukum dan Praktik Perwakafan di Indonesia, Yogyakarta: Pilar Media, 2005, 30-31 
peristiwa di masa yang akan datang, sebab pernyataan wakaf berakibat lepasnya hak milik seketika setelah wakif menyatakan berwakaf. Selain itu berwakaf dapat diartikan memindahkan hak milik pada waktu terjadi wakaf itu.

2. Tujuan wakaf harus jelas, maksudnya hendaklah wakaf itu disebutkan dengan terang kepada siapa diwakafkan. Apabila seseorang mewakafkan harta miliknya tanpa menyebutkan tujuan sama sekali, maka wakaf dipandang tidak sah.

3. Wakaf merupakan hal yang harus dilaksanakan tanpa syarat boleh khiyar. Artinya tidak boleh membatalkan atau melangsungkan wakaf yang telah dinyatakan sebab pernyataan wakaf berlaku tunai dan untuk selamanya.

Selain syarat-syarat umum tersebut diatas, menurut hukum Islam ditentukan pula syarat khusus yang harus dipenuhi oleh orang yang memberikan wakaf dan harta yang diwakafkan, syarat itu adalah: ${ }^{23}$

1. Ada yang berhak menerima wakaf itu bersifat perseorangan.

2. Adapula yang berhak menerima wakaf bersifat kolektif/umum, seperti badan-badan sosial Islam.

Sementara itu, sahnya wakaf sebagaimana disebut dalam Undang-Undang Wakaf no. 41 tahun 2004 pasal 2 dikatakan bahwa, "wakaf sah apabila dilaksanakan menurut syari'ah" ${ }^{24}$. Maka bagi umat Islam, ketentuan mengenai terlaksananya wakaf dengan baik, mempunyai kedudukan yang sangat menentukan, untuk sah atau tidaknya sebuah perwakafan adalah:

\footnotetext{
${ }^{23}$ Abdul Ghofur Anshori, 30-31

24 Kementrian Agama Kabupaten Lampung
}

\section{Wakif}

Wakif ialah pihak yang mewakafkan harta benda miliknya. Suatu perwakafan sah dan dapat dilaksanakan apabila wakif mempunyai kecakapan untuk melakukan tabarru' yaitu melepaskan hak milik tanpa mengharapkan imbalan materiil. Orang dapat dikatakan mempunyai kecakapan tabarru' dalam hal perwakafan, apabila orang tersebut memenuhi syarat yaitu:
a. Merdeka
b. Berakal sehat
c. Dewasa (baligh)
d. Tidak berada di bawah pengampuan (boros/lalai). ${ }^{25}$

Karena wakaf merupakan pelepasan benda dari pemiliknya untuk kepentingan umum, oleh karena itu syarat terpenting dari wakif adalah kecakapan bertindak. Mengenai kecakapan bertindak dalam bukubuku fiqih Islam ada dua istilah yang perlu dipahami yaitu baligh dan rasyid. Baligh adalah dewasa, dalam hal ini ulama' berpendapat umur 15 tahun. Yang bertindak atas nama badan hukum itu adalah pengurusnya yang sah menurut hukum. Ketentuan tentang badan hukum yang dapat bertindak menjadi wakif ini merupakan ketentuan baru yang tidak terdapat di dalam hukum Fiqih Islam.

\section{Nadzir}

Nadzir adalah pihak yang menerima harta benda wakaf dari wakif untuk dikelola dan dikembangkan sesuai dengan peruntukannya. Sama halnya dengan wakif, orang yang dipandang sah menjadi nadzir adalah orang dewasa, berakal sehat dan beragama Islam. Sedangkan menurut ketentuan undang-undang wakaf no 41 tahun 2004, seseorang dapat menjadi nadzir apabila memenuhi persyaratan:
a. Warga
b. Warga Negara Indonesia
c. Beragama Islam
d. Dewasa

25 Direktorat Pengembangan Zakat dan Wakaf, 32-33.

Timur, 4. 
e. Amanah

f. Mampu secara jasmani dan rohani

g. Tidak terhalang melakukan perbuatan hukum ${ }^{26}$

Mengingat nadzir adalah pemegang harta yang pada dasarnya harus dikelola secara baik demi kepentingan umat dan masyarakat banyak, maka seorang atau beberapa nadzir harus yang jujur atau amanah (dapat dipercaya).

3. Harta benda wakaf (maukuf)

Yang dimaksud harta benda wakaf adalah harta benda yang di wakafkan oleh wakif kepada nadzir, dalam kaitan ini, harta benda wakaf harus memenuhi persyaratan sebagai berikut:

a. Benda itu adalah milik sah dari pihak yang berwakaf.

b. Benda yang diwakafkan itu tahan lama dan bisa diambil manfaatnya.

c. Benda yang diwakafkan itu harus sesuatu yang boleh dimiliki dan dimanfaatkan, karena itu tidak boleh mewakafkan seekor babi atau benda-benda haram lainnya.

d. Kadar benda yang diwakafkan tidak boleh melebihi jumlah sepertiga harta yang berwakaf, sebab hal ini bisa merugikan pihak ahli waris dari yang berwakaf. ${ }^{27}$

Perbuatan mewakafkan tanah milik adalah suatu perbuatan yang suci, mulia dan terpuji sesuai dengan ajaran Islam. Oleh karena itu tanah yang diwakafkan harus betul-betul merupakan hak milik yang tidak ada cacatnya dilihat dari sudut pemilikanya. Selain itu tanah yang akan diwakafkan tersebut tidak sedang menjadi tanggungan hutang/hak tanggungan, tidak dibebani oleh

26 Kementrian Agama Kabupaten Lampung Timur, 8

27 Helmi Karim, Fiqh Muamalah, Jakarta: Raja Grafindo Persada, Cet-2, 1997, 109-110. jaminan lain serta tidak dalam sengketa. Jadi harus benar-benar tanah yang sempurna.

\section{Ikrar Wakaf (sighat)}

"Wakaf dinyatakan sah dengan mengucapkan lafaz, "Aku wakafkan, peruntukkan buat sabiilillaah, aku tahankan sejumlah ejian buat keperluananya" atau "Tanahku kuwakafkan, atau wakaf diberlakukan atas barang ini”. ${ }^{28}$

Tujuan dibuatnya akta ikrar wakaf tersebut adalah untuk memperoleh pembuktian yang kuat atau otentik dan sebagai salah satu persyaratan untuk pendaftaran tanah wakaf pada Kantor Badan Pertanahan Nasional setempat. Di samping itu juga mencegah timbulnya persengketaan tanah wakaf di kemudian hari.

\section{Peruntukan Harta Benda Wakaf (maukuf'alaih)}

"Para ulama madzhab sepakat bahwa disyaratkan untuk barang yang diwakafkan itu persyaratan-persyaratan yang ada pada barang yang dijual, yaitu barang tersebut konkret dan milik orang yang mewakafkan.,"29

Wakaf harus dimanfaatkan dalam batasbatas yang sesuai dan diperbolehkan syari'at Islam.Syarat-syarat peruntukan harta benda wakaf adalah qurbat atau pendekatan diri kepada Allah. Wakaf adalah perbuatan yang bertujuan mendekatkan diri kepada Allah. Oleh karena itu yang menjadi obyek atau tujuan wakafnya harus obyek kebajikan yang termasuk dalam bidang qurbat kepada Allah.

\section{Jangka Waktu Wakaf}

Yang dimaksud dengan jangka waktu wakaf ialah harta benda wakaf yang diserahkan itu dimaksudkan untuk jangka waktu yang panjang dan atau bahkan untuk selama-lamanya, bukan untuk waktu sesaat. Untuk jangka waktu ini sangat terkait erat

${ }^{28}$ Zainuddin bin Abdul Aziz al-Malibari alFannani, Terjemahan Fat-Hul Mu'in Jilid 2, Bandung: Sinar Baru Algesindo, 2005, 1018

${ }^{29}$ Siah Khosi'ah,. 41 
dengan unsur harta benda wakaf yang diharuskan tahan lama.

"Para ulama mazhab, kecuali Maliki, berpendapat bahwa, wakaf tidak terwujud kecuali bila orang yang mewakafkan bermaksud mewakafkan barangnya untuk selama-lamanya dan terus-menerus. Itu sebabnya, maka wakaf disebut sebagai shadaqah jariyah". ${ }^{30}$

Mengenai syarat jangka waktu bahwa wakaf haruslah bersifat permanen dan merupakan pendapat yang didukung oleh mayoritas ulama. Bahwa wakaf harus diberikan untuk selamanya (permanen) dan harus disertakan statemen yang jelas untuk itu. Dan wakaf boleh bersifat sementara dan sah baik dalam jangka waktu yang panjang maupun pendek.

\section{Macam-macam Wakaf}

"Ditinjau dari segi tujuan atau peruntukan wakaf, pada dasarnya dibagi menjadi dua bentuk, yaitu pertama, wakaf ahli atau wakaf khusus adalah wakaf yang peruntukkannya untuk orang-orang tertentu, seorang atau lebih baik itu keluarga wakif maupun orang lain". 31

Wakaf ahli ini kerap dan banyak juga terjadi dikalangan masyarakat. Bentuk wakaf ini, di dalam prakteknya mirip dengan lembaga Adat yang berbentuk pusaka. Hanya bedanya, kalau wakaf Ahli pemberiannya itu tidak terkait harus ditunjukkan hanya untuk keluarga wakaf atau keturunan, melainkan dapat diberikan kepada siapa saja sesuai dengan keinginan si wakif, baik kepada orang-orang yang masih terkait hubungan kekeluargaan dengan si wakif ataupun tidak. ${ }^{32}$

Wakaf ahli atau wakaf dzurri sering juga disebut wakaf alal aulad adalah wakaf yang diperuntukkan bagi kepentingan dan jaminan sosial dalam lingkungan keluarga atau lingkungan kerabat sendiri. ${ }^{33}$

${ }^{30}$ Muhammad Jawad Mughniyah, 635

31 Muhammad Daud Ali, Sistem Ekonomi Islam, Jakarta: UI Press, 2008,. 90

32 Taufik Hammami, Perwakafan Tanah dalam Politik Hukum Agraria Nasional, Jakarta: PT. Tatanusa, 2003, 66.

${ }^{33}$ Siah Khosi'ah, 63
"Dalam satu segi, wakaf ahli ini baik, karena si wakif mendapatkan dua kebaikan, yaitu kebaikan dari amal ibadah wakaf juga kebaikan dari silaturrahmi terhadap keluarga yang diberikan wakaf". "Wakaf semacam ini dipandang sah dan yang berhak menikmati harta wakaf itu adalah orangorang yang ditunjuk dalam pernyataan wakaf". 34

Akan tetapi pada sisi lain wakaf ahli ini sering memunculkan masalah. Seperti halnya bagaimana kalau anak cucu yang ditunjuk sudah tidak ada lagi, siapa yang berhak mengambil manfaat benda wakaf tersebut, atau sebaliknya, bagaimana jika anak cucu si wakif yang menjadi tujuan wakaf itu berkembang sedemikian rupa, sehingga menyulitkan bagaimana cara meratakan pembagian hasil harta wakaf tersebut.

"Pada perkembangan selanjutnya, wakaf dzurri dianggap kurang dapat memberikan manfaat bagi kesejahteraan umum karena sering menimbulkan kekaburan dalam pengeluaran dan pemanfaatan wakaf oleh keluarga yang diserahi harta wakaf'. ${ }^{35}$

Akan tetapi pada sisi lain wakaf ahli ini sering memunculkan masalah. Seperti halnya bagaimana kalau anak cucu yang ditunjuk sudah tidak ada lagi, siapa yang berhak mengambil manfaat benda wakaf tersebut, atau sebaliknya, bagaimana jika anak cucu si wakif yang menjadi tujuan wakaf itu berkembang sedemikian rupa, sehingga menyulitkan bagaimana cara meratakan pembagian hasil harta wakaf tersebut.

"Pada perkembangan selanjutnya, wakaf ahli untuk saat ini dianggap kurang dapat memberikan manfaat bagi kesejahteraan umum, karena sering menimbulkan kekaburan dalam pengelolaan dan pemanfaatan wakaf oleh keluarga yang diserahi harta wakaf'. ${ }^{36}$

${ }^{34}$ Departemen Agama, Fiqih Wakaf, Jakarta: Direktorat Pengembangan Zakat Dan Wakaf, 2005, 15-16

${ }^{35}$ Hendi Suhendi, Fiqh Muammalah, Jakarta: PT Raja Grafindo Persada, 2002, 244

${ }^{36}$ Siah Khosi'ah, 70 
Yang kedua ialah wakaf khairi atau wakaf umum adalah wakaf yang diperuntukkan bagi kepentingan atau kemaslahatan umum, atau sering kita kenal dengan wakaf sosial.

"Wakaf jenis ini jelas sifatnya sebagai lembaga keagamaan dan lembaga sosial dalam bentuk masjid, madrasah, pesantren, asrama, rumah sakit dan rumah yatim piatu". 37

Wakaf khairi atau wakaf sosial inilah yang sesuai dengan ajaran Islam danyang dianjurkan pada orang yang mempunyai harta untuk melakukannya guna memperoleh pahala yang terus mengalir bagi orang yang bersangkutan kendatipun ia meninggal dunia selama wakaf itu masih dapat dimanfaatkan.

Dalam penggunaannya wakaf khairi jauh lebih banyak manfaatnya dibandingkan dengan wakaf ahli. Karena tidak terbatasnya pihak-pihak yang mengambil manfaatnya. Dalam jenis wakaf ini wakif dapat mengambil manfaatnya dari harta yang diwakafkan itu, seperti halnya masjid maka wakif boleh mempergunakannya (mengambil manfaatnya). ${ }^{38}$

Secara subtsansinya, wakaf inilah yang merupakan salah satu cara untuk membelanjakan (memanfaatkan) harta di jalan Allah SWT. Dan harta benda yang diwakafkannya pun benar-benar terasa manfaatnya untuk kepentingan umum.

Wakaf khairi ini sudah sesuai dengan tujuan ibadah wakaf itu sendiri, yakni untuk kemaslahatan umat, baik di bidang ekonomi, pendidikan dan sasaran sosial kemasyarakatan lainya. Wakaf ini sangat kecil sekali kemungkinanya untuk disalahgunakan, karena yang memilikinya bukan perseorangan. Dengan demikian, benda wakaf tersebut benar-benar terasa pemanfaatanya untuk kepentingan umum, tidak hanya untuk keluarga atau kerabat yang terbatas.

Ditinjau dari segi waktu atau kelanjutannya sepanjang zaman, wakaf ini dibagi 2, yaitu: wakaf abadi dan wakaf sementara. Wakaf abadi ialah wakaf yang diikrarkan selamanya dan tetap berlanjut sepanjang zaman. Wakaf yang dapat dimanfaatkan dalam jangka waktu yang panjang, tidak habis dalam sekali pakai, hal ini dikarenakan wakaf itu lebih mementingkan manfaat dari benda tersebut. Wakaf yang sebenarnya dalam Islam adalah wakaf abadi, yang pahalanya berlipat ganda dan terus berjalan selama wakaf itu masih ada. Pahala wakaf ini mengalir untuk wakif selama wakafnya terus berlangsung. Wakaf ini disebut shadaqah jariyah yang paling sempurna bentuknya.

Keabadian wakaf biasanya berlangsung secara alami pada wakaf tanah. Sedangkan bangunan dan benda lainnya tidak mungkin berlangsung kekal tanpa ada penambahan barang baru lainnya, baik itu berupa perawatan dan rehabilitasi yang berkelanjutan atau mengganti benda baru atas kebijakan Nazhir wakaf atau pimpinan perusahaan yang bendanya mengalami kerusakan karena sering digunakan.

Apabila wakaf tidak mempunyai sumber dana untuk pembiayaan perawatandan rehabilitasi, maka semua wakaf selain wakaf tanah hasilnya sementara, karena semua wakaf selain tanah akan rusak dan punah.

"Wakaf sementara ialah wakaf yang sifatnya tidak abadi, baik dikarenakan oleh bentuk barangnya maupun keinginan wakif sendiri". ${ }^{39}$

\section{Wakaf dalam Perudang-undangan di Indonesia}

PP No. 28 Tahun 1977 berlaku sejak tanggal 17 Mei 1977. Dengan berlakunya PP No. 28 Tahun 1977 tentang Perwakafan Tanah Milik, maka ketentuan tentang perwakafan tanah milik yang ada sebelumnya, sepanjang bertentangan dengan PP No. 28 Tahun 1977 ini, tidak berlaku lagi. Segala sesuatu yang berkenaan dengan wakaf haruslah mengikuti ketentuanketentuan yang terdapat di dalam PP No. 28 Tahun 1977 dan peraturan pelaksanannya.

\footnotetext{
${ }^{37}$ Muhammmad Daud Ali, . 90

${ }^{38}$ Departemen Agama, h. 17
}

39 Mundzir Qahaf, Manajemen Wakaf Produktif, Jakarta: Khalifa, 2005, 25 
Menurut Pasal 1 ayat (1) Peraturan Pemerintah Nomor 28 Tahun 1977 Perwakafan mulai dibenahi dengan melakukan pembaharuan-pembaharuan di bidang pengelolaan dan paham wakaf secara umum. Paling tidak, pelaksanaan pembaharuan paham yang selama ini sudah dan sedang oleh para pihak yang berkepentingan dengan wakaf. ${ }^{40}$

Menurut Undang-Undang Nomor 41 Tahun 2004 "Badan Wakaf Indonesia merupakan lembaga independen dalam melaksanakan tugasnya. Badan Wakaf Indonesia berkedudukan di ibukota Negara Kesatuan Republik Indonesia dan dapat membentuk perwakilan di provinsi dan / atau kabupaten / kota sesuai dengan kebutuhan. ${ }^{41}$

Melihat kepada tugas-tugas yang dibebankan kepada BWI, badan ini mempunyai fungsi sangat strategis terutama dalam rangka pembinaan dan pengawasan terhadap nazhir untuk dapat melakukan pengelolaan wakaf secara produktif. Diperlukan sumber daya manusia yang benar-benar mempunyai kemampuan dan kemauan dalam mengelola wakaf, berdedikasi tinggi dan memiliki komitmen dalam pengembangan wakaf serta memahami masalah wakaf serta hal-hal yang terkait dengan wakaf.

Untuk dapat diangkat menjadi anggota BWI, setiap calon anggota harus memenuhi persyaratan, yaitu warga negara Indonesia, beragama Islam, dewasa, amanah, mampu secara jasmani dan rohani, tidak terhalang melakukan perbuatan hukum, memiliki pengetahuan, kemampuan, dan / atau pengalaman di bidang perwakafan dan / atau ekonomi, khususnya di bidang ekonomi syari'ah, dan mempunyai komitmen yang tinggi untuk mengembangkan perwakafan nasional. Pertimbangan BWI ditetapkan oleh para anggota.

\footnotetext{
40 Direktorat Pengembangan Zakat dan Wakaf, 98-99

41 Kementrian Agama Kabupaten Lampung Timur, 24-25
}

Dalam rangka melaksanakan tugas dan wewenangnya tadi, susunan organisasi BWI terdiri atas:

a. Badan Wakaf Indonesia terdiri atas Badan Pelaksana dan Dewan Pertimbangan.

b. Badan Pelaksana dimaksud pada ayat (1) merupakan unsur pelaksana tugas Badan Wakaf Indonesia.

c. Dewan Pertimbangan sebagaimana dimaksud pada ayat (1) merupakan unsur pengawas pelaksanaan tugas Badan Wakaf Indonesia.

d. Badan Pelaksana dan Dewan Pertimbangan sebagaimana dimaksud dalam pasal 51 masing-masing dipimpin oleh 1 (satu) orang ketua dan 2 (dua) orang wakil ketua yang dipilih dari dan oleh para anggota.

Praktik wakaf yang terjadi dalam kehidupan masyarakat belum sepenuhnya berjalan tertib dan efisien sehingga dalam berbagai kasus harta benda wakaf tidak terpelihara sebagaimana mestinya, terlantar atau beralih ke tangan pihak ketiga dengan cara melawan hukum. Keadaan demikian itu, tidak hanya karena kelalaian atau ketidakmampuan Nazhir dalam mengelola dan mengembangkan harta benda wakaf tetapi karena juga sikap masyarakat yang kurang peduli atau belum memahami status harta benda wakaf yang seharusnya dilindungi demi untuk kesejahteraan umum sesuai dengan tujuan, fungsi, dan peruntukan wakaf.

Berdasarkan pertimbangan di atas dan untuk memenuhi kebutuhan hukum dalam rangka pembangunan hukum nasional perlu dibentuk Undang-Undang tentang Wakaf. Pada dasarnya ketentuan mengenai perwakafan berdasarkan syariah dan peraturan perundang-undangan dicantumkan kembali dalam Undang-Undang ini, namun

42 Usman Suparman, Hukum Perwakafan di Indonesia, Jakarta: Darul Ulum Pres, 2009,20 
terdapat pula berbagai pokok pengaturan yang baru antara lain sebagai berikut:

a. Untuk menciptakan tertib hukum dan administrasi wakaf guna melindungi harta benda wakaf, Undang-Undang ini menegaskan bahwa perbuatan hukum wakaf wajib dicatat dan dituangkan dalam akta ikrar wakaf dan didaftarkan serta diumumkan yang pelaksanaannya dilakukan sesuai dengan tata cara yang diatur dalam peraturan perundang-undangan yang mengatur mengenai wakaf dan harus dilaksanakan. UndangUndang ini tidak memisahkan antara wakaf-ahli yang pengelolaan dan pemanfaatan harta benda wakaf terbatas untuk kaum kerabat (ahli waris) dengan wakaf-khairi yang dimaksudkan untuk kepentingan masyarakat umum sesuai dengan tujuan dan fungsi wakaf.

b. Ruang lingkup wakaf yang selama ini dipahami secara umum cenderung terbatas pada wakaf benda tidak bergerak seperti tanah dan bangunan, menurut Undang-Undang ini Wakif dapat pula mewakafkan sebagian kekayaannya berupa harta benda wakaf bergerak, baik berwujud atau tidak berwujud yaitu uang, logam mulia, surat berharga, kendaraan, hak kekayaan intelektual, hak sewa, dan benda bergerak lainnya. Dalam hal benda bergerak berupa uang, Wakif dapat mewakafkan melalui Lembaga Keuangan Syariah. Yang dimaksud dengan Lembaga Keuangan Syariah adalah badan hukum Indonesia yang dibentuk sesuai dengan peraturan perundang-undangan yang berlaku yang bergerak di bidang keuangan syariah, misalnya badan hukum di bidang perbankan syariah. Dimungkinkannya wakaf benda bergerak berupa uang melalui Lembaga Keuangan Syariah dimaksudkan agar memudahkan Wakif untuk mewakafkan uang miliknya.

c. Peruntukan harta benda wakaf tidak semata-mata untuk kepentingan sarana ibadah dan sosial tetapi juga diarahkan untuk memajukan kesejahteraan umum dengan cara mewujudkan potensi dan manfaat ekonomi harta benda wakaf. Hal itu memungkinkan pengelolaan harta benda wakaf dapat memasuki wilayah kegiatan ekonomi dalam arti luas sepanjang pengelolaan tersebut sesuai dengan prinsip manajemen dan ekonomi Syariah.

d. Untuk mengamankan harta benda wakaf dari campur tangan pihak ketiga yang merugikan kepentingan wakaf, perlu meningkatkan kemampuan profesional Nazhir.

e. Undang-Undang ini juga mengatur pembentukan Badan Wakaf Indonesia yang dapat mempunyai perwakilan di daerah sesuai dengan kebutuhan. Badan tersebut merupakan lembaga independen yang melaksanakan tugas di bidang perwakafan yang melakukan pembinaan terhadap Nazhir, melakukan pengelolaan dan pengembangan harta benda wakaf berskala nasional dan internasional, memberikan persetujuan atas perubahan peruntukan dan status harta benda wakaf, dan memberikan saran dan pertimbangan kepada Pemerintah dalam penyusunan kebijakan di bidang perwakafan. 
Memanfaatkan benda wakaf berarti menggunakan benda wakaf tersebut. Sedang benda asalnya/pokoknya tetap tidak boleh dijual, dihibahkan atau diwariskan. Namun, kalau suatu ketika benda wakaf itu sudah tidak ada manfaatnya, atau kurang memberi manfaat demi kepentingan umum kecuali harus melakukan perubahan pada benda wakaf tersebut, seperti menjual, merubah bentuk / sifat, memindahkan ketempat lain atau menukar dengan benda lain.

Dalam Undang-Undang Nomor 41 Tahun 2004 tentang wakaf juga mengatur tentang perubahan dan pengalihan harta wakaf yang sudah dianggap tidak atau kurang berfungsi sebagaimana maksud wakaf itu sendiri. Secara prinsip, harta benda wakaf yang sudah diwakafkan dilarang:
a. dijadikan jaminan;
b. disita;
c. dihibahkan;
d. dijual;
e. diwariskan;
f. ditukar; atau
g. dialihkan dalam bentuk
pengalihan hak lainnya.

Namun, ketentuan tersebut dikecualikan apabila harta benda wakaf yang telah diwakafkan digunakan untuk kepentingan umum sesuai dengan Rencana Umum Tata Ruang (RUTR).

Berdasarkan ketentuan dan peraturan perundang-undangan yang berlaku dan tidak bertentangan dengan syarie ah. Pelaksanakan ketentuan sebagaimana dimaksud pada ayat (1) hanya dapat dilakukan setelah memperoleh ijin tertulis dari Menteri atas persetujuan Badan Wakaf Indonesia.

Harta benda wakaf yang sudah diubah statusnya karena ketentuan pengecualian tersebut wajib ditukar dengan harta benda yang manfaat dan nilai tukar sekurang kurangnya sama dengan harta benda wakaf semula.

Dengan demikian perubahan benda wakaf pada prinsipnya bisa dilakukan

${ }^{43}$ Usman Suparman, 20 selama memenuhi syarat-syarat tertentu dan dengan mengajukan alasan-alasan sebagaimana yang telah ditentukan oleh Undang-Undang yang berlaku. Ketatnya prosedur perubahan benda wakaf itu bertujuan untuk meminimalisir penyimpangan peruntukan dan menjaga keutuhan harta wakaf agar tidak terjadi tindakan-tindakan yang dapat merugikan eksistensi wakaf itu sendiri. Sehingga wakaf tetap menjadi alternatif untuk meningkatkan kesejahteraan masyarakat banyak.

\section{Pemanfaatan Harta Benda Wakaf di Luar Ikrar}

Perubahan harta benda wakaf terjadi pro dan kontra diantara para ulama madzahab. Persyaratan pun dikemukakan berkaitan dengan perubahan harta benda wakaf. Perubahan harta benda wakaf menurut ulama ahli fiqh. Yang dimaksud ulama fiqh tersebut adalah antara lain mazdhab empat yaitu Syafi'i, Maliki, Hanafi dan Hambali.

Golongan Malikiyah berpendapat "tidak boleh merubah harta benda wakaf yang berbentuk benda-benda tidak bergerak, walaupun benda itu akan rusak dan tidak menghasilkan sesuatu. Sedangkan untuk benda bergerak golongan Malikiyah "membolehkan", sebab dengan adanya penukaran maka benda itu tidak sia-sia.

Begitu juga golongan Syafi'iyah sangat ketat sekali dalam hal perubahan harta benda wakaf, karena wakaf itu sifatnya mengikat, abadi dan tidak bisa ditarik kembali atau diperjual belikan, digadaikan, diwariskan, dan dihibahkan oleh wakif sekalipun wakaf itu telah rusak dan hilang manfaatnya.

Karena wakaf itu bersifat abadi, sehingga kondisi apapun benda wakaf tersebut harus dibiarkan sedemikian rupa. Dasar yang digunakan adalah hadist Nabi yang diriwayatkan oleh Ibnu Umar, dimana dikatakan bahwa benda wakaf tidak boleh dijual, dihibahkan, dan diwariskan.

Golongan Hanafiah mengatakan, bahwa Hanafiyah tidak menentukan ketentuan hukumnya. Karena kedua sahabatnya pun berselisih pendapat, menurut pendapat Abu Yusuf tidak boleh menjual harta benda 
wakaf sekalipun itu rusak, sedangkan menurut pendapat Muhammad bin al-Hasan dikembalikan kepeda pemiliknya yang pertama.

Golongan hanafiah juga berpendapat, boleh melakukan penggantian terhadap benda wakaf tidak bergerak. Mereka membagi penggantian itu dengan 3 bagian yaitu:

a. Wakif sendiri yang mensyaratkan penggantian harta bendanya dilakukan sendiri, atau dilakukan orang lain, atau dilakukan dirinya bersama orang lain. Penggantian harta bendanya dalam keadaan seperti ini boleh dilakukan.

b. Wakif tidak mensyaratkan penggatian harta benda, baik tidak mensyaratkannya atau ia diam saja. Akan tetapi harta bendanya dalam keadaan tidak berguna sama sekali.

c. Waqif tidak mesyaratkan penggatian harta bendanya, akan tetapi harta bendanya, secara umum masih menghasilkan sesuatu. Dan gantinya lebih manfaat. Penggatian wakaf dalam hal seperti ini tidak boleh dilakukan. Demikian menurut pendapat yang terkuat. Pendukung Mazdhad Hanafi tidak mensyaratkan penggantian harta bendanya harus dalam kedaan darurat.

"Madzhab Hanafi menetapkan penggantian wakaf sebagian hak wakif, jika waqif mensyaratkan pelaksanaan pengantian tersebut dilakukan sendiri". ${ }^{44}$

Sedangkan Golongan Hanabilah berpendapat lain, Hanabilah tidak membedakan apakah benda wakaf itu berbetuk masjid atau bukan masjid. Menurut Hanbali wakaf yang sudah hilang mafaatnya boleh diubah dengan cara dijual, ataupun

44 Muh. Anwar Ibrahim, Beberapa Masalah Tentang Wakaf, dalam buku, Majelis Ulama Indonesia, Ijma' Ulama' keputusan Ijtima' Ulama' Komisi Fatwa Se Indonesia III, Jakarta: MUI,2009 ditukarkan meskipun itu masjid. Kemudian hasilnya dibelikan ditukarkan dengan barang yang dapat dijadikan wakaf benda tidak bergerak yang telah diubah.

Hal ini sejalan dengan pendapat Imam An Nawawi "ada yang berpendapat harta benda wakaf yang tidak dapat dimanfaatkan sesuai dengan syarat ditetapkan wakif (pemberi wakaf) boleh dijual, karena tidak dapat dimanfaatkan sesuai dengan syarat yang ditetapkan wakif (pemberi wakaf)" 45

Seperti Imam Ahmad Ibnu Hanbal, Abu Tsaur, dan Ibnu Taimiyah berpendapat akan kebolehannya menjual, mengganti, mengubah atau memindahkan harta benda wakaf yang sudah tidak bermanfaat ataupun rusak, kebolehan itu dikarenakan agar benda wakaf dapat berfungsi atau mendatangkan maslahat sesuai dengan tujuan wakaf, atau mendapatkan maslahat yang lebih besar bagi kepentingan umum, khususnya kaum muslimin.

Dalam hal ini mengacu kepada tindakan Umar Ibn al-Khathab ketika ia memindahkan masjid Kufah dari tempat yang lama ke tempat yang baru. Utsman kemudian melakukan tindakan yang sama terhadap masjid Nabawi mengikuti kontruksi pertama dan melakukan perluasan. Demikian yang terjadi pada Masjidil Haram. ${ }^{46}$

Sebagaimana yang diriwayatkan oleh Bukhori Muslim, bahwa Rasulallah saw bersabda kepada 'Aisyah ra, yang artinya:"Seandainya kaummu itu masih dekat dengan jahilyah, tentulah Ka'bah itu akan aku runtuhkan dan aku jadikan dalam bentuk redah serta aku jadikan baginya dua pintu: satu untuk masuk dan satu untuk keluar". 47

Melihat bahwa ulama yang membolehkan banda wakaf ditukar dan diganti dengan yang lebih baik, maka penulis menganggap dasar yang dilakukan adalah mempertahankan manfaat. Dengan mempertahankan manfaat itulah sama halnya melestarikan kemaslahatan. Sebab

45 Imam Nawawi, Kitab Mugni Al-Muhtaj, Bairut: Dar Al Kutub Al Ilmiyah, III, 550

${ }^{46}$ Depag RI, Fiqh Wakaf, 81

${ }^{47}$ Depag RI, Fiqh Wakaf, 81 
salah satu tujuan benda yang diwakafkan adalah kemaslahatan ummah.

Hal ini menurut penulis sesuai dengan kaidah fiqhiyah:

$$
\text { دَزْعُالْمَفَاسِدَوَجَلْبُ ألمَصَالِحَ }
$$

"menolak segala yang merusak dan menarik segala yang bermanfaat". ${ }^{48}$

Konsep kaidah tersebut adalah menolak segala kerusakan namun mengutamakan kemanfaatan. Artinya, ketika kondisi suatu barang sudah tidak berguna dikarenakan rusak, maka benda tersebut tidak bisa diambil manfaatnya. Agar benda tersebut tetap bisa diambil manfaatnya, penukaran benda menjadi suatu keniscayaan untuk mengembalikan manfaat yang ada pada tersebut.

Dalam hal ini Allah berfirman dalam QS. Al-Baqarah ayat 267:
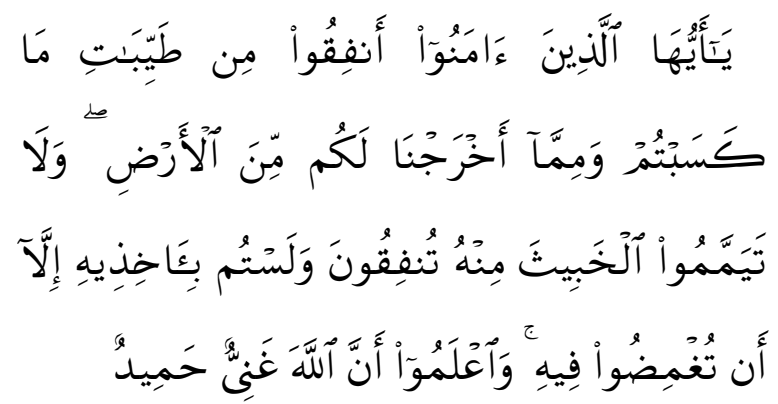

Artinya: "Hai orang-orang yang beriman, nafkahkanlah (di jalan Allah) sebagian dari hasil usahamu yang baik-baik dan sebagian dari apa yang Kami keluarkan dari bumi untuk kamu. dan janganlah kamu memilih yang buruk-buruk lalu kamu menafkahkan daripadanya, padahal kamu sendiri tidak mau mengambilnya melainkan dengan memincingkan mata terhadapnya. dan ketahuilah, bahwa Allah maha kaya lagi maha terpuji". 49

Permasalahan

mempertahankan manfaat sebagai kemaslahatan bagi masyarakat dari sebuah benda wakaf merupakan penanda penting. Para ulama bisa berpendapat seperti itu tidak lepas dari adanya alasan-alasan yang menjadikan suatu hukum bisa berubah. Ketentuan alasan

48 Imam Musbikin, Qowaid Al-fiqhiyah, Jakarta: PT Raja Grafindo Persada, 2001. 37

${ }^{49}$ Departemen Agama RI. 45 tersebut selalu didasarkan pada kondisi benda tersebut yang mana selalu berkaitan dengan khalayak. Dengan kata lain, benda itu tidak akan bermanfaat jika tidak dimanfaatkan oleh orang. Sehingga munculnya alasan maslahah terhadap benda wakaf mengindikasikan adanya upaya penyesuaian hukum terhadap situasi dan kondisi.

Madzhab Hanafi berargumen bahwa penggantian benda wakaf (istibdal al-waqfi) yang tidak bergerak diperbolehkan apabila bendanya tidak berguna sama sekali (la yantafi'u bil kulliyah). Menurutnya, standar ketidakbergunaan benda tersebut adalah apabila tidak bisa menghasilkan sesuatu akan tetapi tidak cukup untuk membayar biayanya. 50

Pendapat madzhab Hanafi menganggap boleh melakukan penggantian benda wakaf tidak bergerak tidak lepas dari adanya alasan (illat). Keberadaan illat dapat dilihat pada inti dari kemanfaatan benda. Madzhab Hanafi tidak melihat dari segi bendanya yang harus dipertahankan walaupun rusak. Sehingga dengan adanya kemanfaatan benda tersebut, masyarakat bias mengambil suatu kemanfaatan dari benda itu.

Dalam Keputusan Komisi B Ijtima' Ulama Komisi Fatwa MUI Se-Indonesia III menjelaskan bahwa penggantian benda wakaf (istibadl al-waqf) diperbolehkan sepanjang untuk merealisasikan kemaslahatan karena untuk mempertahankan keberlangsungan manfaat wakaf (istimrar baqai almanfaah), dan dilakukan dengan ganti yang punya nilai sepadan.

Penggantian benda wakaf dapat dengan cara menjual benda tersebut dan kemudian dibelikan ganti yang sepadan. Untuk itu, MUI dalam melihat masalah ini memperbolehkan dengan adanya kententuan; pertama, adanya hajah dalam rangka menjaga maksud wakif. Kedua, hasil

50 Majelis Ulama Indonesia, Ijma' Ulama' keputusan Ijtima' Ulama' Komisi Fatwa SeIndonesia III, Jakarta: MUI, 2009. Dalam Komisi B Ijma' Ulama' keputusan Ijtima' Ulama' Komisi Fatwa Se Indonesia III tentang Masa'il Fiqhiyah Mu'ashirah, 44. 
penjualannya harus digunakan untuk membeli harta benda lain sebagai wakaf pengganti. Dan ketiga, kemanfaatan wakaf pengganti tersebut minimal sepadan dengan benda wakaf sebelumnya. ${ }^{51}$

UU tentang Wakaf No 41 Tahun 2004 yang membahas masalah hukum perwakafan, banyak pihak yang berharap agar wakaf dapat berdampak positif bagi perkembangan wakaf di Indonesia. Dan sekarang setelah Wakaf No 41 Tahun 2004 terbentuk, maka yang diperlukan selanjutnya adalah penyempurnaan sistem dan pola pengelolaan wakaf sendiri dan keberpihakan pemerintah sebagai pemegang kebijakan nasional. Wakaf perlu dilihat dari perspektif yang jauh ke depan, dan kelahiran Kompilasi Hukum Islam hanyalah salah satu pilar pengelolaan dan pengembangan harta benda wakaf agar berjalan lebih baik, di samping pilar lainnya yang harus dibangun bersama oleh umat Islam.

Dengan adanya Kompilasi Hukum Islam, maka pengelolaan dan pengembangan wakaf akan memperoleh dasar hukum yang lebih kuat serta dapat menampung perkembangan perwakafan di Tanah Air. Benda wakaf yang selama ini baru berupa benda tidak bergerak, dalam Undang-undang No 41 Tahun 2004 diperluas sehingga meliputi benda tidak bergerak dan benda bergerak termasuk uang, logam mulia, surat berharga, kendaraan, hak atas kekayaan intelektual (Haki), hak sewa, dan benda bergerak lainnya sesuai dengan ketentuan syari'ah dan peraturan perundang undangan lainnya.

Mengenai perubahan harta benda wakaf dalam Pasal 225 dalam buku III Kompilasi Hukum Islam mengatakan bahwa "pada dasarnya benda yang telah diwakafkan tidak dapat tidak dapat diubah pendayagunaannya selain yang telah diikrarkan oleh waqif. Tetapi perubahan pendayagunaan boleh dilakukan apabila ada dua sebab yaitu tidak sesuai lagi dengan tujuan wakaf seperti diikrarkan oleh wakif dank arena kepentingan umum." 52

\footnotetext{
${ }^{51}$ Majelis Ulama Indonesia,44

${ }^{52}$ Siah Khosi'ah, 187
}

"Harta benda wakaf berdasarkan Pasal 40 Undang-undang No 41Tahun 2004 suatu harta benda yang telah diwakafkan dilarang: a) dijadikan jaminan, b) disita, c) dihibahkan, d) dijual, e) diwariskan, f) ditukar, atau g) dialihkan dalam bentuk pengalihan hak lainnya". 53

"Suatu perubahan benda wakaf dapat terjadi, dalam pasal 11 Ayat (1) Peraturan Pemerintah Nomor 28 Tahun 1977 pada dasarnya tanah milik yang telah diwakafkan tidak dapat dilakukan perubahan peruntukan atau penggunaan lain yang dimaksud dalam ikrar wakaf'. ${ }^{54}$

Perubahan harta benda wakaf dalam Kompilasi Hukum Islam Pasal 225 ayat (2) menyatakan Penyimpangan dari ketentuan tersebut dimaksud hanya dapat dilakukan terhadap hal-hal tertentu setelah terlebih dahul mendapatkan persetujuan tertulis dari Kepala Kantor Urusan Agama Kecamatan berdasarkan saran dari Majlis Ulama Kecamatan dan Camat setempat dengan Alasan:

a. Karena tidak sesuai lagi dengan tujuan wakaf seperti yang diikrarkan oleh wakif;

b. Karena kepentingan umum. ${ }^{55}$

Dengan syarat ini menunjukkan bahwa negara sangat peka dalam melihat permasalahan wakaf. Wakaf yang dalam arti bahasa adalah menahan kepemilikin pribadi menjadi milik umum memang perlu dilakukan pemeliharaan. Tidak mungkin apabila benda wakaf itu hanya dimanfaatkan saja, sedangkan dalam hal pemeliharaan diabaikan. Apabila tidak dipelihara, justru ketika barang sudah rusak, maka masyarakat tidak bisa memanfaatkan sebagaimana mestinya.

Atas dasar itulah, maka salah satu maksud dari kepentingan umum tersebut tidak lain adalah menjaga hak masyarakat yakni bisa memanfaatkan benda sepanjang masa. Jika dilihat dari sifat benda wakaf

\footnotetext{
${ }^{53}$ Kementrian Agama Kabupaten Lampung Timur,. 20

${ }^{54}$ Peraturan Pemerintah Nomor 28 Tahun 1977

Tentang Perwakafan Tanah Milik

${ }^{55}$ Siah Khosi'ah, 188
} 
yang cenderung abadi, jelas sekali bahwa tidak mungkin benda wakaf akan selalu abadi. Keabadian dapat terlihat pada wujud kemanfaatan dari suatu benda walaupun dalam hal ini benda sudah mengalami perubahan bentuk, akan tetapi subtansi kemanfaatan bisa dimanfaatkan.

Majelis Ulama Indonesia mengatakan penukaran harta benda wakaf diperbolehkan sepanjang untuk merealisasikan kemaslahatan karena untuk mempertahankan keberlangsungan manfaat wakaf, dan dilakukan dengan ganti yang mempunyai nilai sepadan atau lebih baik.

Dalam hal penjualan harta benda wakaf Majelis Ulama Indonesia mempunyai 3 ketentuan:

a. Adanya hajah dalam rangka menjaga maksud wakif,

b. Hasil penjualannya harus digunakan untuk membeli harta benda lain sebagai wakaf pengganti,

c. Kemanfaatan wakaf pengganti tersebut minimal sepadan dengan benda wakaf sebelumnya. ${ }^{56}$

Dalam hal ini sama seperti halnya pendapat Imam al-Nawawi dalam kitab Mugni al-Muhtaj:

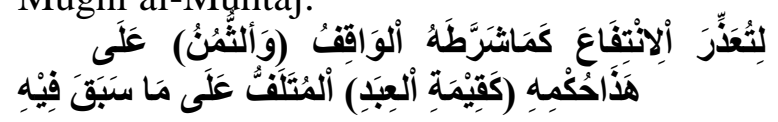

Artinya : "ada yang berpendapat harta benda wakaf yang tidak dapat dimanfaatkan sesuai dengan syarat ditetapkan wakif (pemberi wakaf) boleh dijual, karena tidak dapat dimanfaatkan sesuai dengan syarat yang ditetapkan wakif (pemberi wakaf) ${ }^{, 57}$.

Dari sini, penulis menemukan titik temu, bahwa harta benda yang telah diwakafkan dapat dilakukan perubahan menurut Hukum Islam dengan jalan Istihsan, "Istihsan yaitu mencari kebaikan, menurut Usul fiqh yaitu berpaling dari pada

\footnotetext{
${ }^{56}$ Majelis Ulama Indonesia,. 49

${ }^{57}$ Imam Nawawi, 550
}

hukum yang mempunyai dalil kepada adat (kebiasaan) untuk kemaslakhatan umum'. ${ }^{58}$

Begitu juga yang dijelaskan dalam Komplasi Hukum Islam pasal 225 bahwa harta benda wakaf yang telah diwakafkan tidak dapat dilakukan perubahan, akan tetapi dari penyimpangan tersebut dapat dilakukan karena tidak sesuai lagi dengan tujuan wakaf seperti yang diikrarkan, dan karena kepentingan umum lainnya.

Dari sisi lain juga dijelaskan dalam UU No 41 Tahun 2004 pasal 40, Namun penyimpangan dari ketentuan pasal 40 huruf (f) Undang-undang No 41 Tahun 2004, hanya dapat dilakukan apabila untuk kepentingan umum sesuai dengan Rencana Umum Tata Ruang (RUTR) berdasarkan ketentuan perundang-undangan yang berlaku dan tidak bertentangan dengan syari'ah. Perubahan sebagaimana dimaksud hanya dapat dilakukan dengan persyaratan adanya ganti rugi sekurang-kurangnya sama dengan nilai harta benda wakaf semula, dan setelah mendapat izin tertulis dari Menteri Agama serta persetujuan dari Badan Wakaf Indonesia.

Dengan begitu penulis dapat memahai bahwa merubah harta benda wakaf yang sudah tidak bermanfaat lagi itu lebih baik, jika dilihat jauh ke depan kebermafaatannya dan benda itu akan menjadi lebih baik.

\section{Pemanfaatan Harta Wakaf di Taman Fajar}

Dalam menjalankan atau mengelola harta benda wakaf, hal yang paling mendasar adalah sifat dan sikap komitmen dari pengelola (Nazhir) sebagai orang yang berwenang dan bertanggung jawab terhadap harta benda wakaf, Berangkat dari sini penulis mencoba memaparkan hasil dari penelitian di Desa Taman Fajar Kec. Purbolinggo Kab. Lampung Timur.

Harta wakaf oleh bapak Basini berupa sebidang tanah dilakukan pada tahun 2012 yang kemudian pada tahun 2013 dibangun mushola yang diberi nama Mushola Taqwa. Setelah dibangun mushola, pemanfaatan

\footnotetext{
${ }^{58}$ Nazar Bakry, Fiqh dan Ushul Fiqh, Jakarta: Raja Grafindo persada, 2004, . 61
} 
harta wakaf Mushola Taqwa desa Taman Fajar berupa tanah pekarangan yang seharusnya dikelola dan keuntungannya digunakan untuk kesejahteraan mushola. Akan tetapi selama ini yang terjadi adalah Nazhir yang salah menggunakan harta benda wakaf itu untuk kepentingan pribadinya. ${ }^{59}$

Hal ini muncul ide dari masyarakat untuk mengelola dan mengembangkan harta wakaf mushola tersebut. Sehingga pada tahun 2014 sampai dengan 2015, warga Taman Fajar sendiri juga antusias mendukung perluasan tanah mushola dengan gotong royong, kemudian bermusyawarah yang di antaranya:

Setelah adanya tanah wakaf untuk kesejahteraan Mushola swadaya masuk ke Mushola dan Nazhir yang mengelola yaitu Bapak Sayuti Hidayah.

Untuk pengembangan pembangunan mushola menggunakan uang dari kas Mushola kemudian apabila terdapat kekurangan maka diambilkan dari tarikan warga sekitar.

Untuk pembangunan dan pengelolaan tanah wakaf madrasah sumber dananya dari swadaya murni kemudian apabila terdapat kekurangan maka diambilkan dari uang kas Mushola.

Dan juga ada faktor dari luar yaitu adanya teguran dari KUA untuk mendaftarkan tanah yang belum bersertifikat dan juga memperbaiki Mushola, yang nantinya akan dibantu oleh KUA. Kemudian dilanjutkan dengan beberapa upaya pembangunan sebagai aplikasi dari ide-ide sebelumnya, dengan mengelola dan mengembangkannya.

a. Wakif dan Susunan Kepengurusan

Dimulai dari informan pertama yakni ketua Nazhir dan ketua Ta'mir Mushola Taqwa yaitu Bapak Sayuti Hidayah, beliau adalah cucu dari wakif Mushola Taqwa yaitu Bapak Basini. Bapak Sayuti Hidayah adalah orang yang paling berperan dalam mengelola harta benda wakaf mushola hingga sampai saat ini dan berperan penting

\footnotetext{
${ }^{59}$ Bapak Sayuti Hidayah, Ketua Nazhir dan Ketua Ta'mir
}

dalam menjadikan wakaf yang semula hanya mushola dan sekarang bisa berkembang pesat, seperti pembangunan fisik mushola yang bagus kemudian perabotan mushola lengkap, begitu juga dengan berdirinya Madrasah Ibtidaiyah, dan juga TPA. Bapak Sayuti Hidayah adalah aktor penting dalam menjalankan harta wakaf Mushola ini. ${ }^{60}$

Bapak Krisnadi, beliau menjelaskan dengan detail dari para wakif, susunan kepengurusan, sistem pengelolaan harta wakaf hingga berkembang seperti saat ini. Wakif Mushola Taqwa yaitu Bapak Basini yaitu kakek dari Bapak Sayuti Hidayah, kemudian ada dua tanah wakaf yang berupa ladang yaitu wakaf ladang pertama wakifnya adalah $\mathrm{H}$. Ibrahim dan Wakif ladang kedua yaitu $\mathrm{Bu}$ Masrifah atau $\mathrm{H}$. Khayin, sedangkan untuk tanah wakaf hasil pengembangan harta wakaf yakni berupa madrasah dan pekarangan mushola, tanah wakaf madrasah wakifnya diatasnamakan Ibu Qibtiyah yakni orang yang paling banyak menyumbang dalam pembelian tanah tersebut dan wakaf pekarangan Mushola di atas namakan Bapak Sayuti Hidayah sendiri yang kemudian dibangun TPA. 61

Seperti yang telah dikatakan Bapak Sayuti Hidayah, Bapak Krisnadi mengatakan bahwa pembelian tanah wakaf pekarangan atau latar mushola adalah urunan atau patungan dari warga sekitar sedangkan pembelian tanah wakaf madrasah adalah sumbangan beberapa orang dengan mengajukan proposal ke beberapa kerabat yang dirasa kaya. ${ }^{62}$

Menurut Bapak Jamingan uang pembelian pekarangan atau latar mushola selain dari shodaqoh masyarakat sekitar ada juga dari luar daerah, kemudian kekurangannya adalah uang pinjaman. Susunan kepengurusan wakaf atau Nazhir

\footnotetext{
${ }^{60}$ Bapak Sayuti Hidayah, Ketua Nazhir dan Ketua Ta'mir

${ }^{61}$ Bapak Krisnadi, Sekertaris Nazhir dan Sekertaris Ta'mir

${ }^{62}$ Bapak Sayuti Hidayah, Ketua Nazhir dan Ketua Ta'mir
} 
dan juga kepengurusan Mushola atau Ta'mir Mushola menurut Bapak Sayuti Hidayah adalah dimulai dari Ketua Nazhir yaitu Bapak Sayuti Hidayah sendiri kemudian Sekertaris Nazhir, yaitu Bapak Krisnadi dan ada juga, Bendahara Nazhir, yakni Bapak Jamingan. Kemudian susunan ta'mir Mushola juga diketuai oleh Bpk Sayuti Hidayah, kemudian Sekertaris Mushola. ${ }^{63}$

Bapak Krisnadi, untuk, Bendahara Mushola Bpk Mukid, di bidang pembangunan ada Bpk Suwondo, dan seksi perlengkapan atau perabot Mushola ada Bpk Mashuri. Dalam hal kepengurusan ini antara Nazhir dan Ta'mir hampir sama karena beberapa orang yang sebagai Nazhir ada juga yang menjabat sebagai Ta'mir Mushola.

b. Sumber Dana dan Manajemen Keuangan

Mengenai sumber pendanaan wakaf mushola sebelum adanya tanah wakaf untuk kesejahteraan mushola yaitu tanah sawah adalah swadaya murni, swadaya murni adalah urunan atau tarikan berasal dari warga desa Taman fajar yang digunakan untuk keperluan mushola, dalam hal ini berbeda dengan uang infak, karena menurut bapak Sayuti Hidayah uang infak adalah uang yang didapatkan dari kotak amal.

Setelah adanya tanah sawah yang menjadi sumber utama dana untuk kesejahteraan mushola, swadaya murni tetap diberlakukan akan tetapi waktunya ditetapkan pada setiap panen raya, tiap warga diwajibkan untuk shodaqoh minimal $10 \mathrm{~kg}$ dari harga gabah. sedangkan hasil pengelolaan tanah anatara tanah wakaf dan tanah perluasan tersebut $100 \%$ masuk untuk kesejahteraan mushola. ${ }^{64}$

Bapak Krisnadi mengatakan untuk wakaf ladang dari si wakif yakni Ibu Basini digarap pewakif sendiri akan tetapi hasilnya tetap $100 \%$ untuk kesejahteraan mushola, kemudian hasil pengelolaan kedua tanah

\footnotetext{
${ }^{63}$ Bapak Jamingan, Bendahara Nazhir

${ }^{64}$ Bapak Sayuti Hidayah, Ketua Nazhir dan Ketua Ta'mir
}

tersebut langsung masuk ke bendahara mushola akan tetapi terlebih dahulu melewati atau mengetahui bendahara Nazhir. ${ }^{65}$

Menurut Bapak Sofyan sebagai bendahara Nazhir mengakui bahwa Bendahara Nazhir hanya sebagai perantara uang hasil pengelolaan kedua tanah wakaf dan sama sekali tidak memegang uang hasil panen dari kedua tanah tersebut, karena uang tersebut setelah diterima, langsung diberikan kepada bendahara Mushola.

\section{c. Pengelolahan Harta Wakaf}

Dalam menjalankan atau mengelola harta benda wakaf, hal yang paling mendasar adalah sifat dan sikap komitmen dari pengelola (Nazhir) sebagai orang yang berwenang dan bertanggung jawab terhadap harta benda wakaf, Berangkat dari sini penulis mencoba memaparkan hasil dari penelitian di Desa Taman Fajar Kec. Purbolinggo Kab. Lampung Timur.

Harta wakaf oleh bapak Basini berupa sebidang tanah dilakukan pada tahun 2012 yang kemudian pada tahun 2013 dibangun mushola yang diberi nama Mushola Taqwa. Setelah dibangun mushola, pemanfaatan harta wakaf Mushola Taqwa desa Taman Fajar berupa tanah pekarangan yang seharusnya dikelola dan keuntungannya digunakan untuk kesejahteraan mushola. Akan tetapi selama ini yang terjadi adalah Nazhir yang salah menggunakan harta benda wakaf itu untuk kepentingan pribadinya. ${ }^{66}$

Pengelolaan harta tanah wakaf Mushola, dua tanah wakaf ladang, Pembagian pengalokasian uang hasil dari beberapa sumber dana tersebut juga dijelaskan, untuk uang dari swadaya murni masuk ke Mal Mushola dan kemudian digunakan untuk pesangon Guru Madrasah dan TPA serta untuk biaya keperluankeperluan ngaji. Untuk pembangunan dan perlengkapan Mushola dananya diambilkan

\footnotetext{
${ }^{65}$ Bapak Krisnadi, Sekertaris Nazhir dan Sekertaris Ta'mir

${ }^{66}$ Bapak Sayuti Hidayah, Ketua Nazhir dan Ketua Ta'mir
} 
dari Kas Mushola, apa bila ada kekurangannya maka diambilkan dari tarikan warga. Sedangkan Untuk pembangunan madrasah pengambilan dananya dari swadaya atau tarikan dari warga kemudian kekurangannya diambilkan dari kas Mushola. ${ }^{67}$

Bapak Jamingan sebagai bendahara Nazhir mengenai sistem keuangan ini sangat meresahkan seperti yang beliau ungkapkan, karena sistem pengelolaan keuangan wakaf Mushola Taqwa menurut beliau tugas dan fungsi masing-masing pengurus mempunyai tanggung jawab yang berbeda, oleh karena itu perlu adanya kejelasan kembali di bidang pengurusan, terutama di bidang keuangan, agar di kemudian hari tidak terjadi permasalahan karena sudah jelas siapa yang bertanggung jawab di bidangnya masingmasing. Masalahnya sistem keuangan antara uang hasil tanah wakaf sawah dengan uang mushola seperti infak, wakaf, shodaqoh digabungkan menjadi satu karena bendahara mushola tidak membedakan uang yang masuk antara uang infak, shodaqoh, jariyah, swadaya murni atau tarikan tiap tahun dari warga.dan hasil pengelolaan kedua tanah wakaf.

\section{Hukum Memanfaatkan Harta Wakaf Untuk Kepentingan Usaha Menurut Hukum Islam}

Menurut Syafii, Malik dan Ahmad, wakaf itu adalah suatu ibadah yang disyariatkan. Hal ini disimpulkan baik dari pengertian-pengertian umum ayat AlQur'an maupun hadis yang secara khusus menceritakan kasus-kasus wakaf di zaman Rasulullah.

Sedikit sekali memang ayat Al-Qur'an dan as-Sunnah yang menyinggung tentang wakaf. Karena itu, sedikit sekali hukumhukum wakaf yang ditetapkan. Berdasarkan kedua sumber tersebut. Meskipun demikian ayat Al-Qur'an dan as- Sunnah yang sedikit itu mampu menjadi pedoman para ahli fiqih Islam. Sejak masKhulafau Rasyidin sampai sekarang, dalam membahas dan

\footnotetext{
${ }^{67}$ Bapak Sayuti Hidayah, Ketua Nazhir dan Ketua Ta'mir
}

mengembangkan hukum-hukum wakaf melalu ijtihad mereka sebab itu sebagian besar hukum-hukum wakaf dalam Islam ditetapkan sebagai hasil ijtihad, dengan menggunakan metode ijtihad yang bermacam-macam, seperti qiyas dan lainlain.

Apabila kita lihat dari permasalahan hukum pemanfaatan perekonomian di atas tanah wakaf menurut hukum Islam, ada beberapa ketetuan yang harus dipahami terlebih dahulu. Pertama, siapakah yang menjadi Nazhir (pengelola wakaf). Kedua, apakah pribadi dan keluarga yang dimaksud, kedudukannya sebagai pengelola atau sekedar peminjam harta wakaf. Berikutnya yang harus diketahui pula adalah pengertian Nazhir itu sendiri, kewajiban Nazhir sumber dana pengelolaan aset wakaf, dan upah Nazhir.

Hal-hal yang boleh dan tidak bolah dilakukan oleh Nazhir adalah:

Hal-hal yang boleh dilakukan Nazhir :

a. Menyewakan harta wakaf yang hasilnya digunakan untuk kepentingan wakaf, seperti membangun, mengembangkan dan memperbaiki kerusakannya.

b. Menanami tanah wakaf kalau aset wakaf tersebut berupa perkebunan.

c. Membangun permukiman untuk disewakan.

d. Mengubah kondisi harta wakaf.

e. Hal-hal yang tidak boleh dilakukan oleh Nazhir

f. Melakukan dominasi (monopoli) atas harta wakaf.

g. Tidak boleh menggadaikan harta wakaf

h. Tidak boleh mengizinkan seseorang untuk menggunakan harta wakaf tanpa bayaran.

i. Tidak boleh meminjam harta wakaf.

Wakaf dimaksudkan untuk memberikan manfaat seluas-luasnya, karena itu diperlukan usaha untuk mengembangkan supaya produktif. Untuk itu, tentu memerlukan biaya yang diperoleh dari :

Dana Khusus yang disiapkan si wakif untuk pembangunan. 
Jika harta wakaf sifatnya siap pakai dan siap dimanfaatkan, maka diambil dari hasil pengelolaannya.

Harta wakaf yang siap digunakan secara langsung, dana pengelolahannya dibebankan kepada orang yang menggunakan harta tersebut.

Harta wakaf yang digunakan untuk kepentingan umum, biasanya dana pengelolaannya diambil dari baitul mal (pemerintah) kalau tidak ada maka di bebankan kepada masyarakat umum yang memanfaatkan fasilitas tersebut.

Secara teknis wakaf diartikan sebagai aset yang dialokasikan untuk kemanfaatan umat dimana substansi atau pokoknya ditahan, sementara manfaatnya boleh dinikmati untuk kepentingan umum.

Wakaf dikelolah oleh Nazhir yang merupakan pengemban amanah wakif. Makna wakaf dari segi bahasa dan teknis terkait dengan adanya "keabadian" unsur pokok wakaf. Ada beberapa pendapat mengenai unsur "keabadian" dalam wakaf tersebut, di antaranya : (i) Imam Syafi'i, sangat menekankan wakaf pada fixed asset (aset tetap) sekaligus menjadi syarat sah wakaf (ii) Imam Hanafy, menekankan kepada "natural" barang yang diwakafkan baik itu aset tetap maupun aset bergerak; dan (iii) Imam Maliki, keabadian umur aset wakaf adalah relatif tergantung umur ratarata aset yang diwakafkan. Dari pendapatnya ini, Imam Maliki memperluas lahan (area) wakaf mencakup barang-barang bergerak lain seperti wakaf susu sapi begitu juga aset yang paling likuid seperti uang tunai yang bisa digunakan untuk mendukung pemberdayaan potensi wakaf secara produktif. Yang menjadi substansinya adalah sapi dan yang diambil manfaatnya adalah susu.

Dari beberapa pendapat di atas, pendapat Imam Maliki dirasa sangat relevan dengan semangat pemberdayaan wakaf secara produktif dan tetap mempertahankan "keabadian" aset wakaf, karena sesuai dengan Sabda Nabi "Ihbis ashlaha wa tashaddaq tsamrataha" yang berarti substansi wakaf tidak semata-mata terletak pada pemeliharaan bendanya, tapi yang jauh lebih penting adalah nilai manfaat dari benda tersebut untuk kepentingan umum, termasuk untuk pemanfaatan tanah wakaf.

Jadi, berdasarkan keterangan di atas bahwa hukum pemanfaatan tanah wakaf untuk kepentingan usaha menurut hukum Islam adalah hukumnya Jais (boleh), asalkan dalam hasil usaha dalam pemanfaatan tanah wakaf untuk kemasalatan umum, bukan untuk kepentingan pribadi.

9. Hukum Memanfaatkan Harta Wakaf Untuk Kepentingan Usaha Menurut UU Wakaf No 41 Tahun 2004

Pengertian Wakaf itu sendiri sebagai mana diatur dalam Pasal 1 Undang-undang No. 41 Tahun 2004 Tentang Wakaf adalah perbuatan hukum wakif untuk memisahkan dan/atau menyerahkan sebagaian harta benda miliknya untuk dimanfaatkan selamanya atau untuk jangka waktu tertentu sesuai dengan kepentigannya guna keperluan ibadah dan/atau kesejahteraan umum menurut syariah.

Di dalam Undang-undang Nomor 4 Tahun 2004 Tentang Wakaf, peruntukan harta benda wakaf tidak semata-mata untuk kepentingan sarana ibadah dan sosial tetapi juga diarahkan untuk memajukan kepentingan umum dengan cara mewujudkan potensi dan manfaat ekonomi harta benda wakaf. Hal ini memungkinkan pegelola harta benda wakaf dapat memasukan wilayah kegiatan ekonomi dalam arti luas sepanjang pegelolaan tersebut sesuai dengan prinsip manajemen dan ekonomi syariah.

Begitu juga dalam hal pemanfaatan tanah wakaf menurut Undang-undang Nomor 41 Tahun 2004 Tentang Wakaf, memperbolehkan melakukan pengelolaan secara produktif atau usaha di atas tanah wakaf berdasarkan Pasal 22 "Dalam rangka mencapai tujuan dan fungsi wakaf, harta benda wakaf hanya dapat diperuntuhkan bagi :

a. Sarana dan kegiatan ibadah

b. Sarana dan kegiatan pendidikan serta kesehatan 
c. Bantuan kepada fakir miski, anak terlantar, yatim piatu, beasiswa:

d. Kemajuan dan peningkatan ekonomi umat; dan/atau

e. Kemajuan kesejahteraan umum lainnya yang tidak bertentangan dengan syariah dan peraturan perundang-undangan.

Dari ketentuan Pasal 22 di atas, bahwa pengelolaan dan pengembangan harta wakaf dilakukan dengan tujuan fungsi, dan peruntukannya yaitu: dilakukan sesuai dengan prinsip syariah, dilakukan secara produktif antara lain cara pengumpulan, invetasi, penanaman modal, produksi, kemitraan, perdagangan, agrousaha, pertambangan, perindustrin, pengembangan teknologi, pembangunan gedung, apartemen, rumah susun, pasar swalayan, pertokoan, perkantoran, sarana pendidikan, ataupun sarana kesehatan dan digunakan Lembaga Penjamin syariah, yakni badan hukum yang menyelengarakan kegiatan penjamin atas suatu kegiatan usaha yang dapat dilakukan antara lain melalui skim asuransi syariah atau skim lain ketentuan peraturaan perundang-undangan.

Hal ini juga berlaku untuk pemanfaatan tanah wakaf untuk kepentingan usaha yang harus berdasarkan tujuan dan fungsi wakaf yaitu kemajuan dan peningkatan ekonomi umat dan atau kesejahteraan umum yang tidak bertentangan dengan syariah dan peraturan perundang-undangan.

\section{KESIMPULAN}

Berdasarkan uraian hasil penelitian dan pembahasan yang dikemukakan pada babbab sebelumnya, maka dalam hal ini dapat diambil kesimpulan yakni sebagai berikut:

Hukum pemanfaatan tanah wakaf untuk kepentingan usaha pribadi menurut hukum Islam adalah hukumnya haram dan tidak boleh dilakukan.

Menurut Undang-undang Nomor 41 Tahun 2004 Tentang Wakaf, memperbolehkan melakukan pengelolaan secara produktif atau usaha di atas tanah wakaf dalam rangka mencapai tujuan dan fungsi wakaf sepanjang tidak bertentangan dengan syariah.

Kepada masyarakat Taman Fajar pengguna daripada tanah wakaf yang dijadikan pemukiman, hendaknya dalam penggunaan tanah wakaf tersebut digunakan sebagaimana mestinya benda wakaf.

Kepada Nadhzir dari perwakafan tanah ini, mohon agar dalam pengawasan terhadap pemanfatan tanah wakaf tersebut, dilakukan secara seksama. Hal ini dimaksudkan untuk menghindari penyalahgunaan benda wakaf.

Bagi keluarga yang ingin mewakafkan (calon wakif) dengan objek tanah, sebelum melakukan perwakafan sebaiknya dilakukan musyawarah bersama anggota keluarga besar untuk membicarakan tentang dampak positif dan negatif yang akan terjadi setelah pelaksanaan perwakafan.

Kepada pejabat yang berwenang (PPAIW) agar tanah yang telah diwakafkan dan diikrarkan supaya segera dibuatkan Akta Ikrar Wakaf (AIW) dan kemudian didaftarkan ke Kantor Pertanahan sebagai bukti otentik telah melakukan perwakafan, guna meminimalisir terjadinya sengketa wakaf yang akan muncul dikemudian hari oleh para ahli waris atau pihak-pihak yang bersangkutan dengan wakaf.

\section{DAFTAR PUSTAKA}

Abdul Ghofur Anshori, Hukum dan Praktik Perwakafan di Indonesia, Yogyakarta: Pilar Media, 2005

Adrian Sutedi, Peralihan Hak Atas Tanah dan Pendaftarannya, Jakarta: Sinar Grafika, 2009

Al-Nawawi, Imam Muhidin, Shahih Muslim, Beirut: Darul Ma'rifah li alThaba'ah wa al-Nasyar wa al-Tauzi, 1992

Cholid Narbuko, Metodologi Penelitian, Jakarta: Bumi Aksara, 2009

Depag RI, Fiqh Wakaf, Direktorat Pemberdayaan Wakaf Direktorat Jendral Bimbingan Masyarakat Islam Departemen Agama RI, 2006

Departemen Agama RI, Al-Hikmah AlQur'an dan Terjemahnya, Bandung: Diponegoro, 2010 
Departemen Agama, Fiqih Wakaf, Jakarta: Direktorat Pengembangan Zakat Dan Wakaf, 2005

Departemen Pendidikan Nasional, Kamus Besar Bahasa Indonesia, Balai Pustaka,

Direktorat Pengembangan Zakat dan Wakaf, Paradigma Baru Wakaf di Indonesia, Direktorat Jendral Bimbingan Masyarakat Islam dan Penyelenggaraan Haji, 2005

Helmi Karim, Fiqh Muamalah, Jakarta, Grafindo Persada, 2002

Hendi Suhendi, Fiqh Muammalah, Jakarta: PT Raja Grafindo Persada, 2002

Imam Musbikin, Qowaid Al-fiqhiyah, Jakarta: PT Raja Grafindo Persada, 2001

Imam Nawawi, Kitab Mugni Al-Muhtaj, Bairut: Dar Al Kutub Al Ilmiyah, III

Kementrian Agama Kabupaten Lampung Timur, Undang-Undang No 41 tahun 2004 Tentang Wakaf

Mahmud Syalthut Ali As-Sayis, Fiqih Tujuh Madzhab, Bandung: Pustaka Setia, 2000

Majelis Ulama Indonesia, Ijma' Ulama' keputusan Ijtima' Ulama' Komisi Fatwa Se-Indonesia III, Jakarta: MUI, 2009.

Marjuqi Yahya, Panduan Fiqih Imam Safi'I, Jakarta Timur: Al-Maghfirah, tt

Muh. Anwar Ibrahim, Beberapa Masalah Tetnag Wakaf, dalam buku, Majelis Ulama Indonesia, Ijma' Ulama' keputusan Ijtima' Ulama' Komisi Fatwa Se Indonesia III, Jakarta: MUI, 2009

Muhammad Ali, Kamus Lengkap Bahasa Indonesia Modern, Jakarta: Pustaka Amani, 2008

Muhammad Daud Ali, Sistem Ekonomi Islam, Jakarta: UI Press, 2008

Muhammad Jawad, Mughniyah, Fiqih Lima Madhab, Jakarta: Lentera, 2002

Mundzir Qahaf, Manajemen Wakaf Produktif, Jakarta: Khalifa, 2005

Mustofa Dieb Al-Bigha, Fiqih Islam Lengkap \& Praktis, Surabaya: Insan Amanah, tt
Nazar Bakry, Fiqh dan Ushul Fiqh, Jakarta:

Raja Grafindo persada, 2004

Peraturan Pemerintah Nomor 28 Tahun 1977 Tentang Perwakafan Tanah Milik

Peraturan Pemerintah Republik Indonesia Nomor 42 Tahun 2006 Tentang Pelaksanaan Undang-undang Nomor 41 Tahun 2004 Tentang Wakaf.

Rachmat Syafe'i, Fiqh Muamalah, Jakarta, Pustaka Setia, 2001

Siah Khosyi'ah, Wakaf \& Hibah Perspektif Ulama Fiqh dan Perkembangannya di Indonesia, Bandung: Pustaka Setia, 2010

Sudarsono, Kamus Hukum, Jakarta: Rineka Cipta, 2009

Suharsimi Arikunto, Prosedur Penelitian Suatu Pendekatan Praktek (Edisi Revisi VI), Jakarta: Rineka Cipta, 2006

Sulaiman Rasjid, Fiqih Islam, Bandung: Sinar Baru Algensindo, 2011

Sumadi Suryabrata, Metodologi Penelitian, Jakarta: Rajawali Pers, 2013

Taufik Hammami, Perwakafan Tanah dalam Politik Hukum Agraria Nasional, Jakarta: PT. Tatanusa, 2003

Undang-undang Republik Indonesia Nomor 41 TAHUN 2004 Tentang Wakaf

Usman Suparman, Hukum Perwakafan di Indonesia, Jakarta: Darul Ulum Pres, 2009

Zainuddin bin Abdul Aziz al-Malibari alFannani, Terjemahan Fat-Hul Mu'in Jilid 2, Bandung: Sinar Baru Algesindo, 2005 